\title{
Salicornia L. (Salicornia pusilla J. Woods, S. ramosissima J. Woods, S. europaea L., S. obscura P.W. Ball \& Tutin, S. nitens P.W. Ball \& Tutin, S. fragilis P.W. Ball \& Tutin and S. dolichostachya Moss)
}

\author{
A. J. DAVY, G. F. BISHOP and C. S. B. COSTA $\uparrow$ \\ School of Biological Sciences, University of East Anglia, Norwich NR4 7TJ, UK; and $\dagger$ Departamento de \\ Oceanografia, Fundação Universidade Federal do Rio Grande, C.P. 474, 96201-900 Rio Grande, Brazil
}

Salicornia L. (Chenopodiaceae) is a genus of annual, apparently leafless halophytic herbs that have articulated, succulent stems. A combination of inbreeding, which allows the development of locally differentiated populations, and considerable phenotypic plasticity has created great taxonomic complexity. Taxonomic difficulties have been compounded by very reduced morphology and the inadequacy of dried material in representing a succulent growth form. Although numerous species aggregates, species and microspecies have been described over the last 250 years in attempts to represent the observed variation, there is still no satisfactory taxonomic treatment and it is frequently impossible to assign published information specifically to taxa within Salicornia. Recent commentaries, with different perspectives on the taxonomic problems, are provided by Dalby (1989), Ingrouille (1989) and Rose (1989). This account reviews material referable to all of the taxa recognized provisionally by Stace (1997): Salicornia pusilla J. Woods, S. europaea L. agg. (S. ramosissima J. Woods, S. europaea L. and S. obscura P.W. Ball \& Tutin) and S. procumbens Smith agg. (S. nitens P.W. Ball \& Tutin, S. fragilis P.W. Ball \& Tutin and $S$. dolichostachya Moss). It is possible that only three species ( $S$. pusilla, S. europaea agg. and S. procumbens agg.) should be recognized (Stace 1997), corresponding with the Sections Pusillae, Salicornia \& Dolichostachyae of Scott (1977). We also include relevant information for closely related putative species within the same complex world-wide.

In Salicornia, the main stem and its opposite branches are composed of short, cylindrical or clavate internodes, each with a succulent, photosynthetic covering, conferring the articulated appearance. The

Correspondence: Dr A. J. Davy (fax + 44 1603592250; e-mail a.davy@uea.ac.uk)

*Abbreviated references are used for many standard works; see Journal of Ecology (1975), 63, 335-344. Nomenclature of vascular plants follows Flora Europaea and Stace (1997) for root system tends to be superficial, often penetrating less than $10-20 \mathrm{~cm}$ into the sediment; the main root axis produces few branches in small individuals but larger plants develop several highly branched, woody main roots that originate from near the base of the stem. A pair of opposite, connate, highly reduced leaves constitute no more than a rim at each stem node. At the lower internodes the succulent covering may atrophy, leaving the base of the stem and some branches narrow, wiry and with ridge-like nodes. The arrangement of lateral branches is regularly decussate and in large plants may be of the 4th order; the uppermost primary branches make an angle usually less than $45^{\circ}$ with the main stem and may be straight or curved upwards. At maturity, every branch terminates in a fleshy spike of contiguous, fertile segments; segments have convex or more or less cylindrical sides and each bears an opposite pair of (1-) 3-flowered cymes. The spike, with its decussately arranged dichasial cymes, may be distinctly tapered; it may be tinged red at maturity. The number of fertile segments per spike is variable but shows discontinuities, sometimes associated with species, resulting in modes of $2-4(-12)$ or 3-12 (-22) or (4-) 6-30 fertile segments per spike.

Each cyme consists of a central flower and (usually) two lateral flowers, deeply embedded in fleshy tissue at the proximal end of a segment and subtended by a rim-like upgrowth (which may have a scarious edge) of the segment below. Within a cyme, the florets are usually arranged in a triangle with the central one distinctly distal; the laterals may be either smaller than the central floret or almost as large. The $3(-4)$ minute lobes of the perianth are connate almost to their apex, usually forming a tri-radiate slit through which the stigmas and anthers or pollen may emerge; they become hard or spongy in fruit. Each flower has 1 (anterior) -2 , rarely 0 , stamens. The anther length may be $0.6-1 \mathrm{~mm}$ (with dehiscence after exsertion) or $0.2-0.5 \mathrm{~mm}$ (with dehiscence before exsertion or when not exserted). Styles 2 or style bifid bearing in all 3 plumose stigmatic lobes $c .0 .5-0.7 \mathrm{~mm}$ in length, or 
682

A. J. Davy,

G. F. Bishop \&

C. S. B. Costa
(C) 2001 British

Ecological Society, Journal of Ecology, 89, 681-707 exceeding $1 \mathrm{~mm}$ in some tetraploids. The deeply embedded ovary is unilocular with a solitary basal ovule. The ovoid, flattened seed has a horse-shoe shaped embryo enclosed by a thin, membranous testa bearing hooked hairs (few or numerous, long or short, sometimes mucilaginous) or is sometimes glabrous. Seed mass $0.2-0.8 \mathrm{mg}$ (see VIII C). Putative British species have been characterized as follows:

S. pusilla (one-flowered glasswort). Mostly erect to $25 \mathrm{~cm}$, simple to much branched and bushy. Branches more or less straight. Yellowish-green, becoming brownish or pinkish-yellow, often with pink tips to the branches. Terminal spike short, up to $c .6 \mathrm{~mm}$, with only 2-4 fertile segments. Lower fertile segments $1-1.5 \mathrm{~mm}$ long and $1-1.5 \mathrm{~mm}$ wide at the narrowest point. Cymes one-flowered. Flowers almost circular with a single stamen. Fertile segments disarticulating shortly before the seeds are ripe.

S. europaea (common glasswort). Erect to $35 \mathrm{~cm}$, fairly richly branched. Lowest branches may be nearly as long as the main stem. Dark green becoming yellowgreen and ultimately flushed pink or red. Terminal spike $10-50(-60) \mathrm{mm}$. Fertile segments with distinctly convex sides, the lower ones $2.5-4 \mathrm{~mm}$ long and 3 $4.5 \mathrm{~mm}$ wide at the narrowest point. Central flower distinctly larger than the two laterals.

S. obscura (glaucous glasswort). (Perhaps a variant of $S$. europaea). Usually erect to $40 \mathrm{~cm}$, typically with primary branches only; branches curving upward distally; lowest branches not more than half as long as the main stem. Dull glaucous green with a matt surface becoming dull yellow. Segments with an inconspicuous scarious border up to $0.1 \mathrm{~mm}$ wide. Terminal spike 10 $40(-45) \mathrm{mm}$, and lower fertile segments $2.5-4.5 \mathrm{~mm}$ long and $2.8-4(-5) \mathrm{mm}$ wide at the narrowest point, similar to $S$. europaea.

S. ramosissima ( purple glasswort). (Perhaps a variant of S. europaea). Erect or prostrate, to $40 \mathrm{~cm}$, simple to much branched. Segments with a conspicuous, broad, scarious border c. $0.2 \mathrm{~mm}$ wide. Dark green becoming deep purplish-red. Branches more or less straight. Terminal spike (5-) 10-30 (-40) $\mathrm{mm}$ and lower fertile segments $1.9-3.5 \mathrm{~mm}$ long and $2-4 \mathrm{~mm}$ wide at the narrowest point. Central flower rounded-rhombic to almost circular.

S. nitens (shining glasswort). Typically erect to $25 \mathrm{~cm}$ with primary branches only. Plant smooth, shining, somewhat translucent, green or yellowish green becoming light brownish purple/orange. Sterile segments conspicuously swollen near the top. Terminal spike 12 $40 \mathrm{~mm}$ with lower fertile segments (1.8-) 2-3 (-3.5) $\mathrm{mm}$ long and $1.8-3.5 \mathrm{~mm}$ wide at the narrowest point.

S. fragilis (yellow glasswort). Erect to $40 \mathrm{~cm}$, usually primary branches only, the lowest normally less than one quarter the length of the main stem. Dull green becoming dull yellowish-green. Terminal spike (15-) 25-80 (-100) $\mathrm{mm}$, distinctly tapering. Lower fertile segments more or less cylindrical, 3-5 $\mathrm{mm}$ long and 3-6 mm wide.
S. dolichostachya (long-spiked glasswort). Erect to procumbent, $10-45 \mathrm{~cm}$. Much branched and bushy, the lowest branches about as long as the main stem. Dark green becoming paler or dull yellow/brownish. Terminal spike (25-) 50-100 (-200) mm, distinctly tapering. Lower fertile segments more or less cylindrical, 3-6 $\mathrm{mm}$ long and 3-6 mm wide.

Patterns of variation suggest that individuals exist as members of local, perhaps unique, inbreeding populations and characterization of the populations is more tractable than that of individuals. World-wide there are c. 13 species (Scott 1977) with innumerable variants. Variation within and between taxa is expressed in morphology, chromosome number, life-history characteristics, enzyme electrotypes and DNA polymorphisms. Numerical analysis of morphological variation in the field failed to support a distinction between the diploid species $S$. europaea and $S$. ramosissima (Ingrouille \& Pearson 1987), although Jefferies \& Gottlieb (1982) had found consistent differences at loci coding for six enzymes. Morphological variation in tetraploids of the $S$. dolichostachya group provided evidence for at least two taxa, one of which correlated with $S$. fragilis (Ingrouille et al. 1990). Wolff \& Jefferies (1987a) used a combination of cytological, electrophoretic and morphometric characters to distinguish three groups of populations from Hudson Bay, the Atlantic coast and James Bay of North America. Transplant experiments between upper and lower levels of a salt marsh in north Norfolk, England, indicated genetically fixed differences in growth phenology between local populations (Jefferies et al. 1981). Subsequently, a detailed demographic analysis of reciprocal transplant experiments has shown clear losses of fitness in populations transplanted away from their local, indigenous microhabitats on the marsh and clear selection against alien populations at transplant sites (Davy \& Smith 1985, 1988; Smith 1985). Analysis of ribosomal DNA polymorphism (RFLP) has confirmed the existence of genetically distinct forms but their distribution was correlated with elevation in the marsh tidal frame rather than with morphological characteristics (Davy et al. 1990; Noble 1990; Noble et al. 1992). Luque et al. (1995) have detected DNA polymorphism between three Spanish populations of Salicornia using a RAPD technique.

Succulent plants of mainly moist, saline habitats, particularly coastal salt marshes; they also grow in inland saline areas.

\section{Geographical and altitudinal distribution}

The composite distribution of all taxa of Salicornia in Britain (Fig. 1) faithfully reflects the availability of saltmarsh habitats around the whole coastline. Salicornia is largely absent from British inland salt marshes, despite apparently suitable habitats (Lee 1977), but it occurs in at least one, at Northwich, Cheshire. Some records are not assigned to individual species, or even species aggregates, and so the constituent taxa are more or less 
(C) 2001 British Ecological Society, Journal of Ecology, 89, 681-707

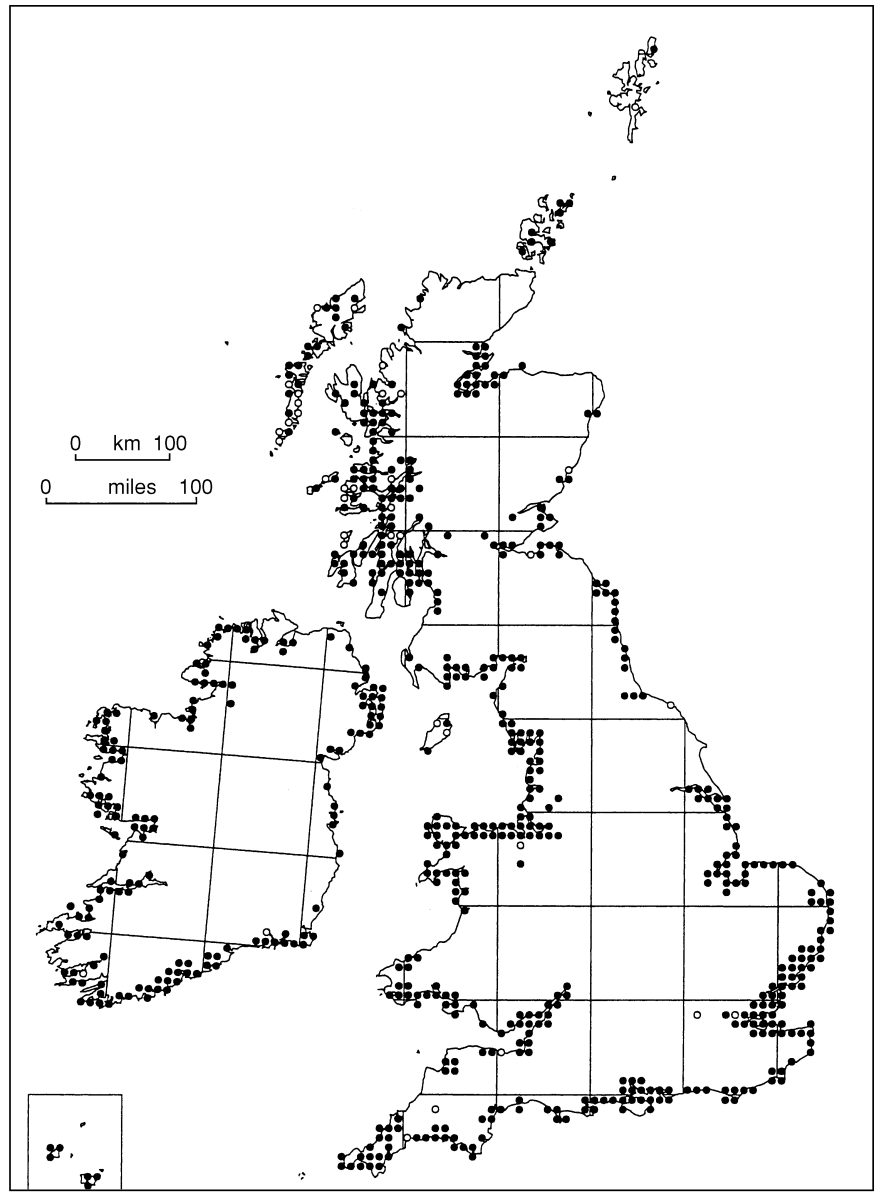

Fig. 1 The composite distribution of all taxa of the genus Salicornia in the British Isles. (O) Pre-1950; (-) 1950 onwards. Each dot represents at least one record in a 10-km square of the National Grid. Mapped by Mrs J. M. Croft, Centre for Ecology and Hydrology, using Dr A. Morton's DMAP programme, mainly from records collected by members of the Botanical Society of the British Isles.

under-recorded. The $S$. europaea agg. is the most widely distributed form (Fig. 2a); S. europaea and $S$. ramosissima both occupy most of its range, whereas records of $S$. obscura are confined to a few locations, mainly in East Anglia and on the Bristol Channel (Fig. 2b-d). The tetraploid S. procumbens agg. (Fig. 3a) is apparently less abundant than $S$. europaea agg., especially in Scotland, Ireland and south-west England, although it is undoubtedly under-recorded; the reasonably distinctive $S$. dolichostachya (Fig. 3b) is the most widely recorded of its constituent taxa and $S$. fragilis (Fig. 3c) also occurs around much of the English and Irish coasts, whereas S. nitens (Fig. 3d) appears to be very sparsely distributed on a latitudinal range from the Isle of Wight to Orkney. The highly distinctive S. pusilla, with its single-flowered cymes, is confined to coastal marshes in the south and east of Britain, from the Humber around to $\mathrm{S}$. Wales and the southern coast of Ireland (Fig. 4).

Salicornia is found around much of the coastline of Europe from the Arctic to the Mediterranean, as well as on the shores of both the Black Sea and Caspian Sea; it is also present sporadically where inland salines occur across Europe (Atl. Fl. Eur.; Fig. 5). Much of this distribution can be tentatively attributed to the $S$. europaea agg. (Fig. 6). Members of the S. procumbens group are recorded from the coasts of the Beloye More inlet of the Barents Sea, the North Sea, the English Channel, the Atlantic coasts of France and Portugal, and the Mediterranean coast of France (Fig. 7). Outside Britain, S. pusilla occurs only on the northern and western coasts of France (Fig. 8).

From Europe and the North African coast, the distribution of Salicornia extends through the near East and Caucasus and central Asia, including much of The Russian Federation, where it forms enormous thickets on solonchaks in steppes and deserts (Fl. URSS 6); it is found again at the coast near Vladivostok, around Sakhalin, and on the Japanese islands of Hokkaido, Honshu and Shikoku (Vergl. Chor.; Hultén 1970). Recently Salicornia has been discovered in Saudi Arabia, in salt marshes on the Arabian Gulf coast and in the sabkha of Al-Aushaziya, some $400 \mathrm{~km}$ from the coast (Al-Turki 1992, 1997). Three (Tolkën 1967) or four (O'Callaghan 1992) species of Salicornia occur around the coast of southern Africa (Tanzania, Madagascar, Mozambique and South Africa). One of these, S. uniflora Tolkën, is analogous with $S$. pusilla in having single-flowered cymes (Tolkën 1967). S. europaea (s.1.) is distributed along the Atlantic coast of N. America and the St. Lawrence seaway. Plants from populations in this complex in arctic coastal marshes around 

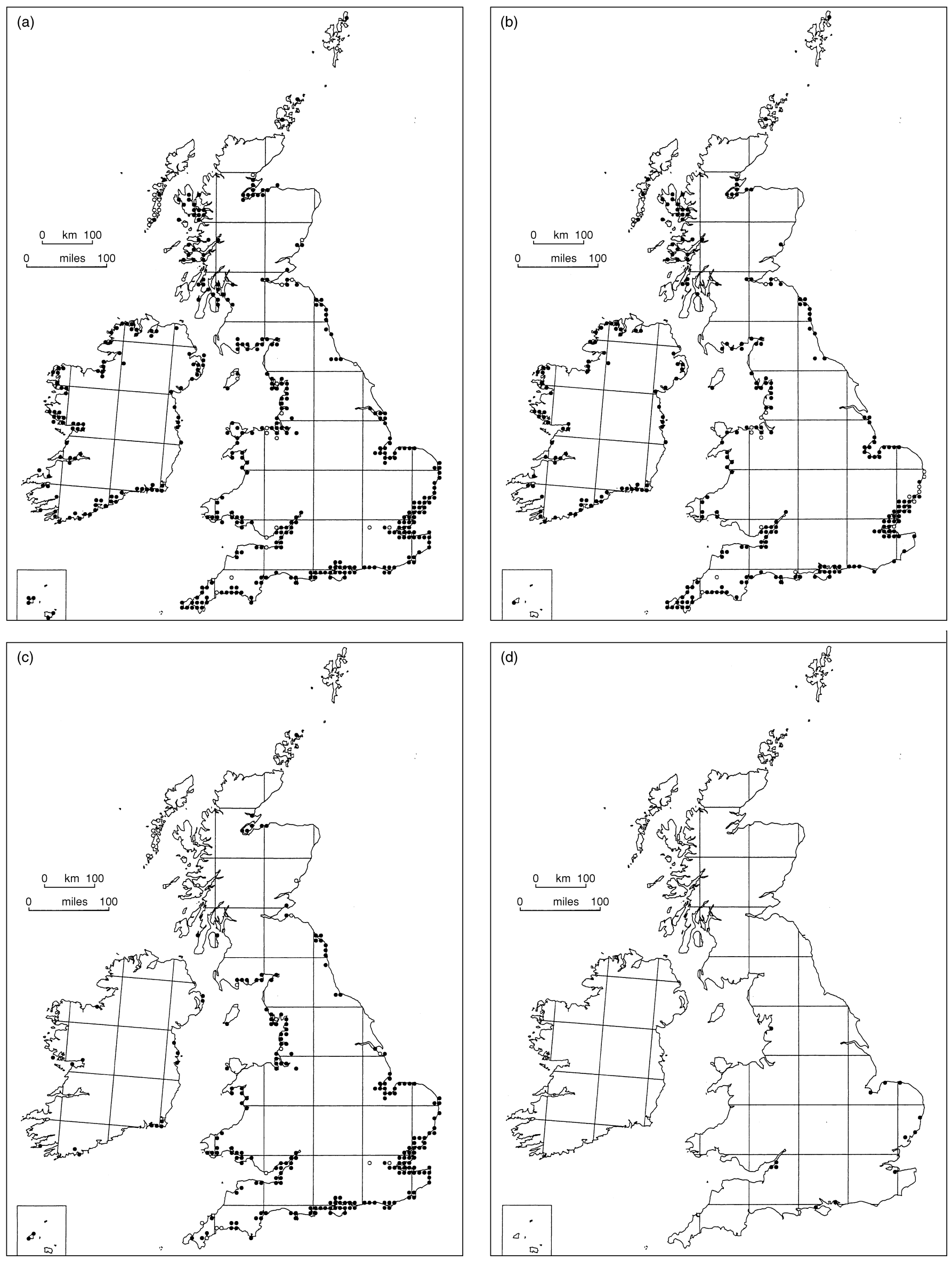

Fig. 2 The distribution of Salicornia europaea agg. in the British Isles. (O) Pre-1950; (-) 1950 onwards. Each dot represents at least one record in a 10-km square of the National Grid. Mapped by Mrs J. M. Croft (see Fig. 1). (a) S. europaea agg., (b) S. europaea, (c) S. ramosissima, and (d) S. obscura. 

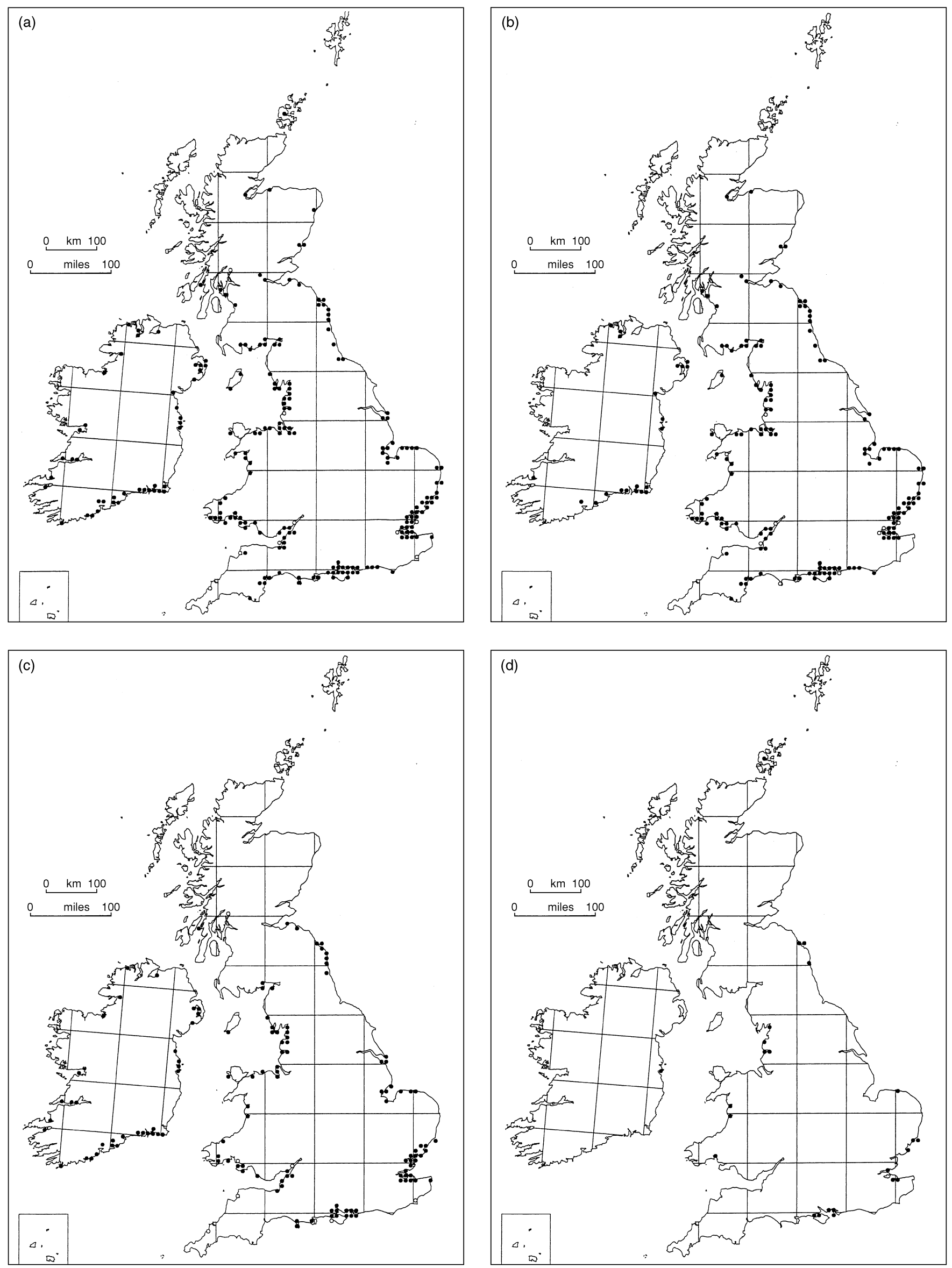

Fig. 3 The distribution of Salicornia procumbens agg. in the British Isles. (O) Pre-1950; (-) 1950 onwards. Each dot represents at least one record in a 10km square of the National Grid. Mapped by Mrs J. M. Croft (see Fig. 1). (a) S. procumbens agg., (b) S. dolichostachya, (c) S. fragilis, and (d) S. nitens. 
686

A. J. Davy,

G. F. Bishop \&

C. S. B. Costa
(C) 2001 British

Ecological Society, Journal of Ecology, 89, 681-707

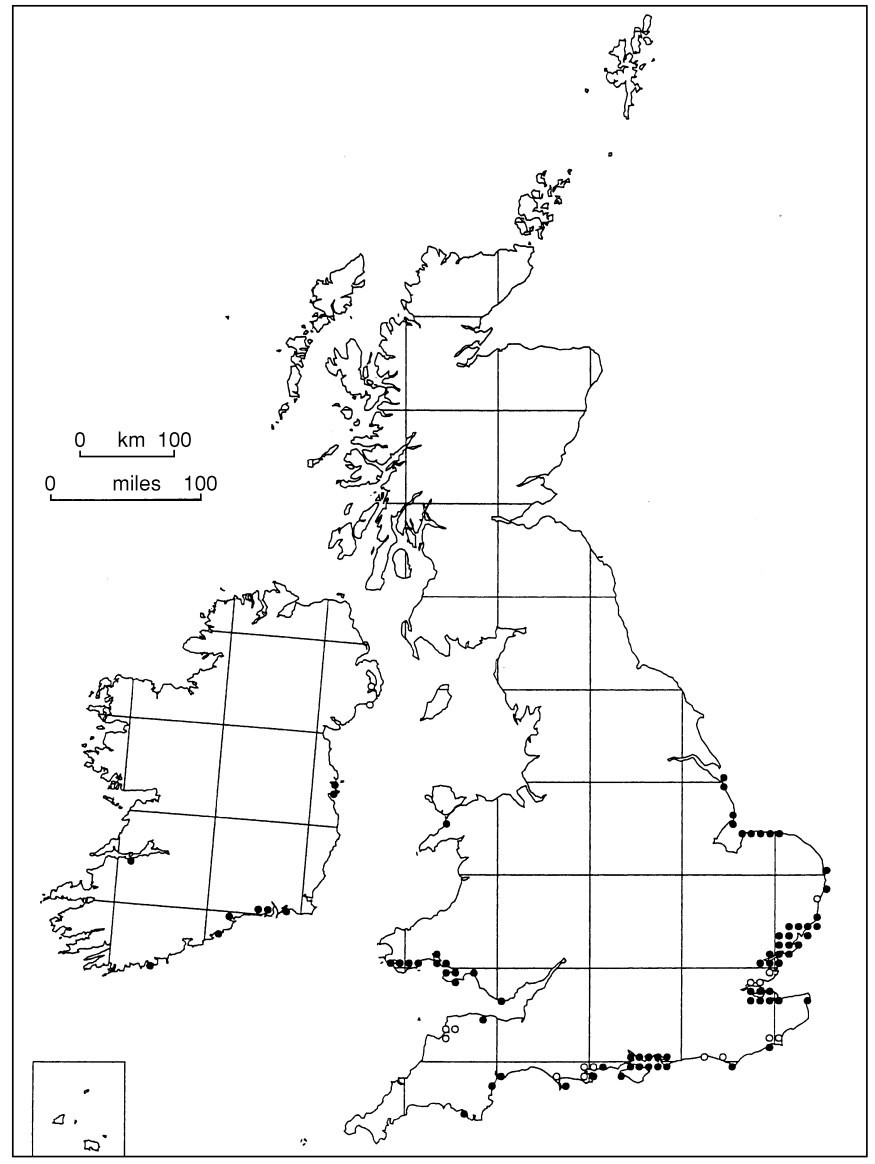

Fig. 4 The distribution of Salicornia pusilla. in the British Isles. (O) Pre-1950; (-) 1950 onwards. Each dot represents at least one record in a 10-km square of the National Grid. Mapped by Mrs J. M. Croft (see Fig. 1).

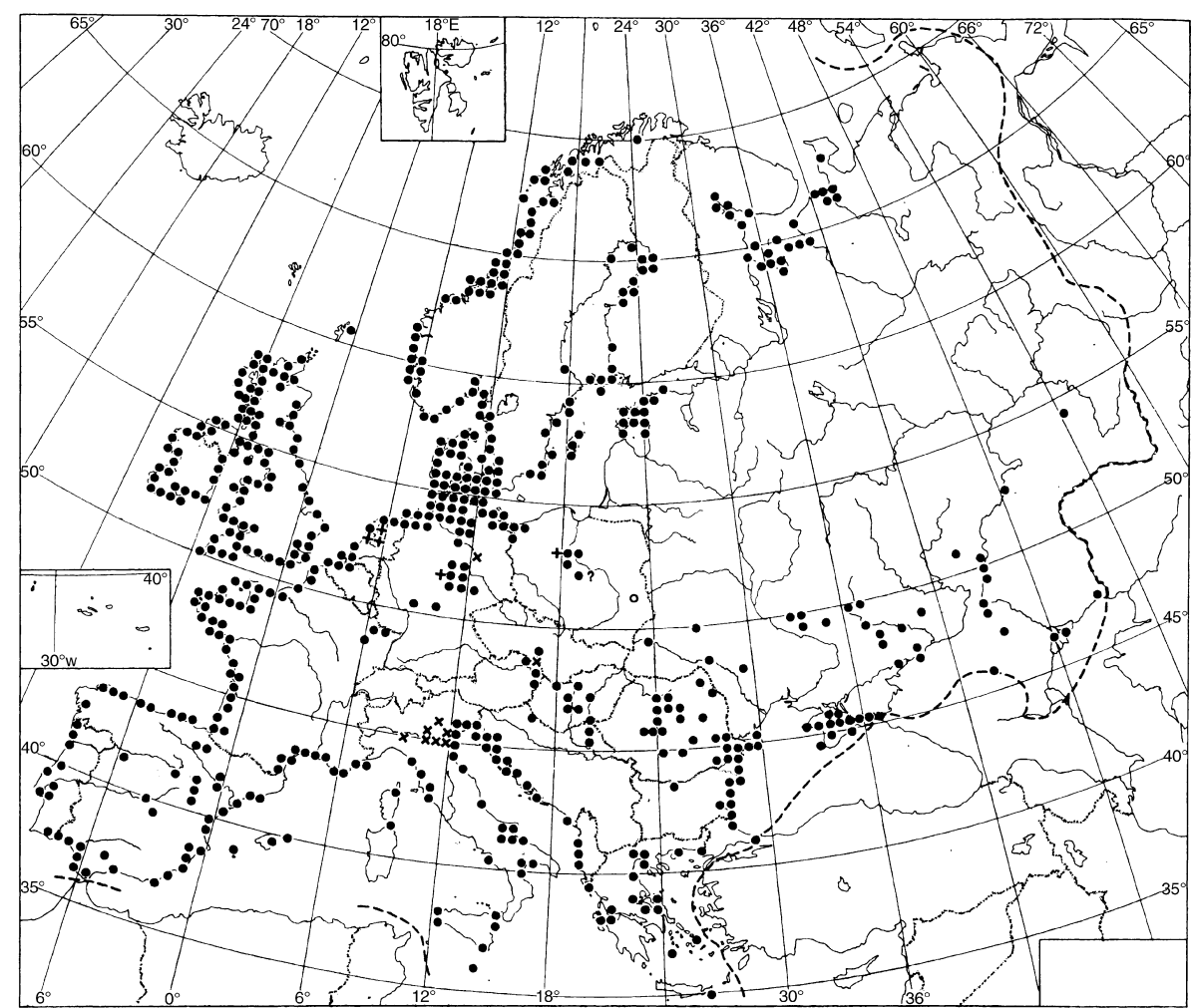

Fig. 5 The distribution of the genus Salicornia in Europe. Each dot $(\bullet)$ represents at least one record in a 50-km square. (+) extinct; $(\times)$ probably extinct. Reproduced from Atl. Fl. Eur., vol. 5 by permission of the Committee for Mapping the Flora of Europe and Societas Biologica Fennica Vanamo. 


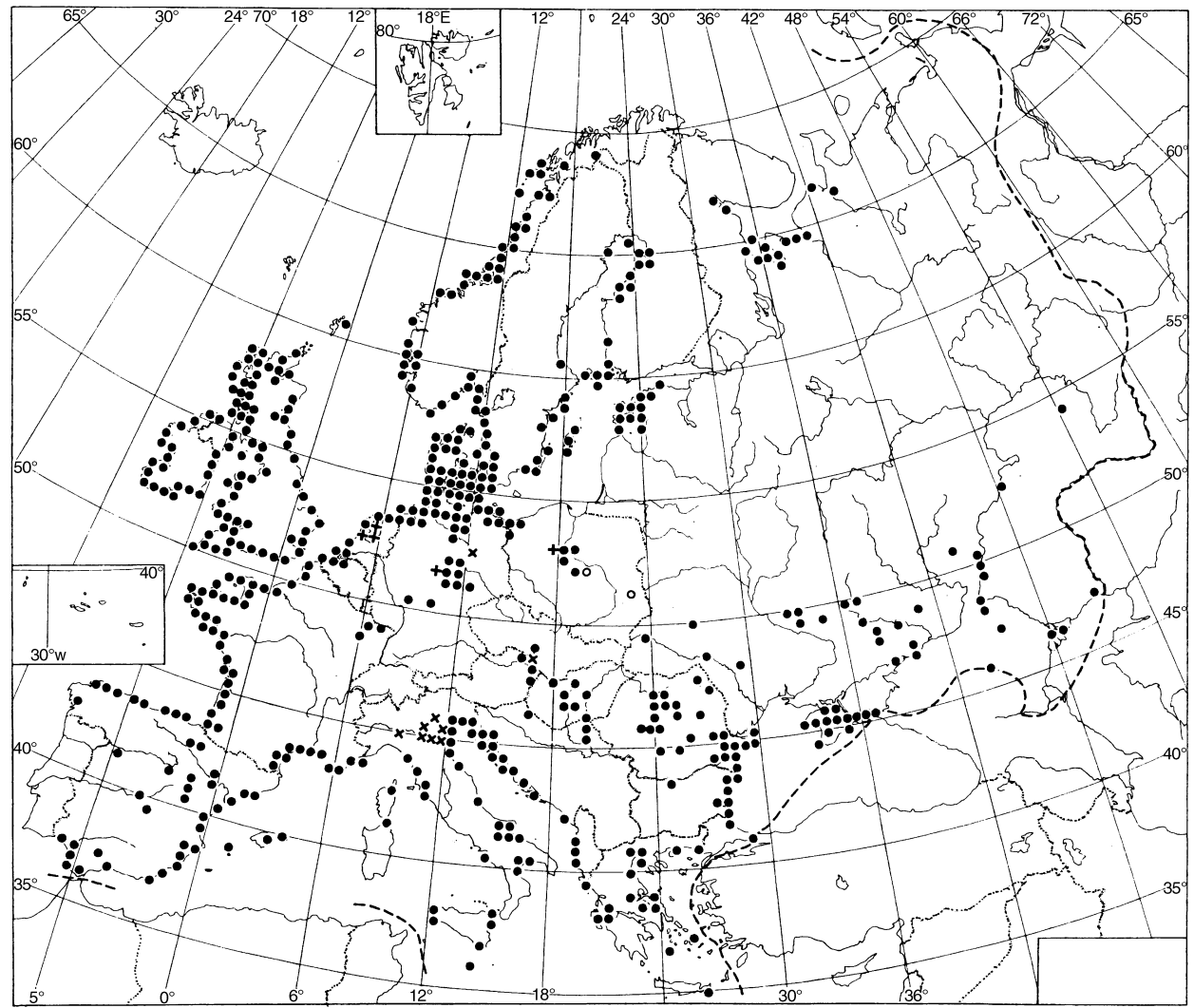

Fig. 6 The distribution of Salicornia europaea agg. in Europe. Each $\operatorname{dot}(\bullet)$ represents at least one record in a 50-km square. $(+)$ extinct; $(\times)$ probably extinct. Reproduced from Atl. Fl. Eur., vol. 5 by permission of the Committee for Mapping the Flora of Europe and Societas Biologica Fennica Vanamo.

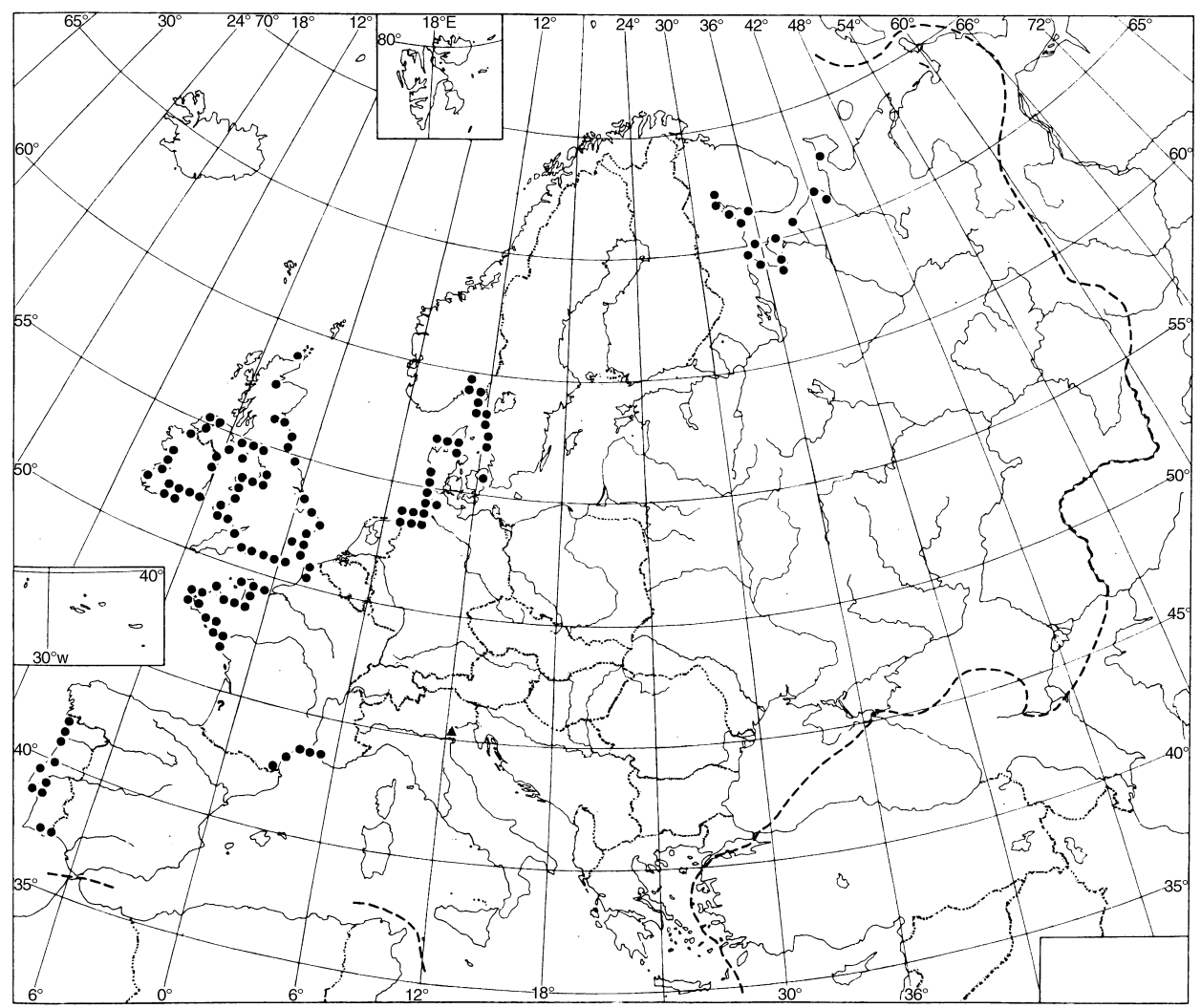

(C) 2001 British

Ecological Society, Journal of Ecology, 89, 681-707
Fig. 7 The distribution of Salicornia procumbens agg. in Europe. Each dot represents at least one record in a 50-km square. ( S. dolichostachya, S. fragilis and S. nitens; $(\mathbf{\Lambda})$ S. veneta. Reproduced from Atl. Fl. Eur., vol. 5 by permission of the Committee for Mapping the Flora of Europe and Societas Biologica Fennica Vanamo. 
688

A. J. Davy,

G. F. Bishop \&

C. S. B. Costa

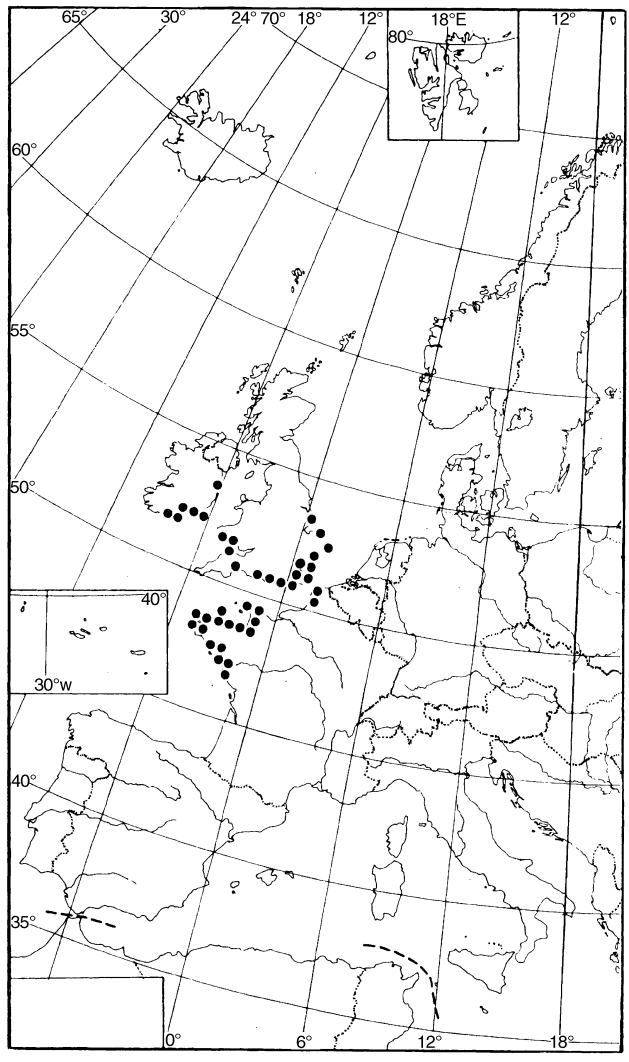

Fig. 8 The distribution of Salicornia pusilla in Europe. Each $\operatorname{dot}(-)$ represents at least one record in a $50-\mathrm{km}$ square. Reproduced from Atl. Fl. Eur., vol. 5 by permission of the Committee for Mapping the Flora of Europe and Societas Biologica Fennica Vanamo.

Hudson Bay have been distinguished as S. borealis Wolff \& Jefferies and $S$. maritima Wolff \& Jefferies (Wolff \& Jefferies 1987b). The form widely distributed in the prairies and salt flats of western North America is generally referred to $S$. europaea ssp. rubra (Nelson) Breitung. Salicornia (s.s.) is absent from Australia, although there are perennial members of the tribe Salicornieae in five other genera (Wilson 1980). Similarly, it is absent from South America, as all species referred to Salicornia there are perennial (i.e., strictly Sarcocornia or Arthrocnemum) (Costa \& Davy 1992).

The altitude of the vast majority of British Salicornia populations is below the level of the highest tides. The inland site at Northwich, Cheshire is at $10 \mathrm{~m}$. However, populations in the sabkha of Al-Aushaziya, Saudi Arabia, are at $650 \mathrm{~m}$ and S. rubra in Montana, USA reaches $1277 \mathrm{~m}$.

\section{Habitat}

\section{(A) CLIMATIC AND TOPOGRAPHICAL LIMITATIONS}

Salicornia has very wide climatic tolerances: subarctic to subtropical and oceanic to continental. Its tolerance of water stress (see VII E) and its annual life history presumably contribute to its ability to survive extreme conditions in adverse seasons. The northern limit of
Salicornia corresponds with the $10{ }^{\circ} \mathrm{C}$ July isotherm; populations at this range limit are virtually confined to low, south-facing slopes, where temperatures may be as much as $7^{\circ} \mathrm{C}$ higher than the north-facing aspect (Jefferies et al. 1983). It is generally limited to unshaded sites with relatively high daily radiant energy availability during the growing season.

Individual populations and taxa of Salicornia may be very sensitive to elevational variations associated with microtopography on the gradient from land to sea of tidal salt marshes. Populations low in the tidal frame need to be more tolerant of prolonged submergence, tidal scour and waterlogging, whereas those at high elevations may experience hypersalinity in summer (Jefferies et al. 1979). In Norfolk, England, S. dolichostachya is among the vascular plants that occurs lowest in the tidal frame, where it experiences more than 600 tidal submergences per annum (Smith 1985; Davy \& Smith 1988). Rozema, van der List et al. (1987) record it occurring mainly below the mean High Water Level in the Netherlands. Salicornia europaea in Norfolk is characteristic of large areas of low marsh, whereas $S$. ramosissima is more typical of pans and interfluves of the upper marsh at slightly higher elevation; S. pusilla is restricted to low hummocks and the landward margin, the highest parts of the tidal frame, where it is often inundated only by spring tides (Davy \& Smith 1988; Noble et al. 1992). Similarly, Rozema, van der List et al. (1987) reported that $S$. europaea agg. ('S. brachystachya (Meyer) König') occurs above Mean High Water Level.

\section{(B) SUBSTRATUM}

Various forms of Salicornia in intertidal habitats grow on a wide range of marine sediments, ranging from gravels and shelly sands, through silts to fine clays. In inland salines, the substrates can also vary from fine clays to coarse sands, depending on their origin. Although Salicornia is an early colonist of soft, unconsolidated sediments, the densest stands tend to be on firm silts and clays (Adam 1981).

Salicornia is invariably associated with saline, brackish or alkaline substrates. The ionic composition of coastal salt marsh substrates generally reflects the ionic balance of seawater, dominated by sodium chloride, but actual concentrations can vary greatly, depending on complex tidal cycles, local evapotranspiration, precipitation and any supply of fresh groundwater. The concentration of $\mathrm{Na}^{+}$ions in the interstitial water from coastal marsh sediments fluctuates greatly, both seasonally and from year to year (Jefferies 1977; Jefferies et al. 1979; Smith 1985). In mid-summer, when successive spring high tides fail to cover the upper marsh and evapotranspiration exceeds rainfall, $\mathrm{Na}^{+}$concentrations in the interstitial water may exceed $1 \mathrm{~m}$ in the upper marsh; conversely, near the winter solstice, the value is typically $0.2-0.3 \mathrm{M}$. The water content of the sediment shows the inverse trend, with low values in summer. Such saline substrata inevitably have exceptionally low water potentials.
Ecological Society, Journal of Ecology, 89, 681-707 
Salicornia L.
During hot, dry summers the water potential $\left(\psi_{w}\right)$ of the upper layers of the sediment can fall rapidly to below $-5.0 \mathrm{MPa}$ (-50 bars); in cooler, wetter summers $\psi_{w}$ potential remains barely below that of sea water, c. $-2.3 \mathrm{MPa}$ (Jefferies et al. 1979). There are many reports of hypersaline soil conditions in sites dominated by $S$. europaea. For instance, Tsuda (1961) recorded up to $8.2 \% \mathrm{NaCl}$ in the soil solution in Japan (cf. 3.5\% total salts in seawater). Salinities in an Ohio salt pan (Ungar et al. 1979), measured as electrical conductivity, reached $143 \mathrm{mS} \mathrm{cm}^{-1}$ (approximately equivalent to $-5.1 \mathrm{MPa} \psi_{w}$ ). Crusts of crystallizing salts are commonly seen at the sediment surface in dry weather. In inland salines, a variety of ions other than $\mathrm{Na}^{+}$and $\mathrm{Cl}^{-}$may predominate.

In coastal marshes, the substrates of Salicornia span the tidal range and are often waterlogged for much or all of the time, depending on elevation and drainage conditions. The saturated sediments are typically hypoxic and may develop low redox potentials, even in the surface layers, with concomitantly high levels of potentially toxic reduced ions such as $\mathrm{S}^{2-}$ and $\mathrm{Mn}^{2+}$ (Ingold \& Havill 1984; Singer \& Havill 1985). See VII (E).

\section{Communities}

The classification of salt marsh vegetation in the British National Vegetation Classification (Rodwell 2000) is based substantially on the work of Adam $(1978,1981)$ who made a phytosociological analysis of relevés from salt marshes all round the British coast. The only community dominated by Salicornia is the 'Annual Salicornia salt marsh' (SM8) or Salicornietum europaeae. Its constant species are at least one of the taxa of Salicornia, which can be of greatly varying density, in a generally open, ephemeral community. Sometimes there are no other species. There is often an algal mat over the substrate surface; in some areas turf fucoids (Fucus vesiculosus ecad caespitosus) may be abundant. Scattered plants of Puccinellia maritima, Suaeda maritima and Spartina anglica may occur, with occasional individuals of Atriplex portulacoides and Aster tripolium (including var. discoideus). Sarcocornia perennis may be present as a rare species. In 81 samples, the mean total cover was $53 \%$, the mean vegetation height was $7 \mathrm{~cm}$ and the mean number of species was three. Within the low marsh, where it characteristically pioneers the colonization of mud flats, the Salicornietum may occur as a distinct zone (from a few metres to several hundred metres wide) or in a mosaic with Spartinetum townsendii or Puccinellietum maritimae (Adam 1981). Extensive pure stands of Salicornia may occur in shallow, poorly drained pans and depressions in higher parts of the marsh.

Salicornia is a constant species in two other communities (SM10 and SM11). 'Transitional low-marsh vegetation with Puccinellia maritima, annual Salicornia species and Suaeda maritima' (SM10) is species-poor and always dominated by complementary proportions of the three constants. It is widespread on lower marshes, where it may be a pioneer community on sandy substrates; on heavily grazed lower marshes with a hummocky Puccinellia maritima community, it tends to occupy the hummock tops, whereas in muddier marshes of south-east England it is found in slight depressions within a variety of other communities. It is also widespread on the sides of large creeks where it occupies a distinct zone above the Salicornietum europaeae. 'Aster tripolium var. discoideus salt marsh' (SM11) or Asteretum tripolii also occurs as an extensive zone on the lower marsh or on creek sides at varying levels in the marsh, with a maximum development at about 350 tidal submergences per year. In addition, 'Zostera noltii stands' (SM1) at their upper elevational limits may grade into Salicornietum. Another essentially annual community, 'Suaeda maritima salt marsh' (SM9) or Suaedetum maritimae can also grade into Salicornietum on the lower marsh. 'Spartina anglica salt marsh' (SM6) or Spartinetum townsendii colonizes marshes at the same elevation as Salicornietum and has now replaced much of it.

The seeds of Salicornia are widely distributed on salt marshes and so it is a variable or minor component of many other communities, where it may find ephemeral niches within the matrix of perennial species: 'Spartina maritima salt marsh' (SM4); 'Arthrocnemum perenne (Sarcocornia perennis) stands' (SM7); 'Rayed Aster tripolium on salt marshes' (SM12); 'Puccinellia maritima salt marsh' (SM13) or Puccinellietum maritimae (in both the 'Limonium vulgare-Armeria maritima subcommunity' or General Salt Marsh, as well as the 'Puccinellia maritima-Spartina maritima subcommunity'); 'Halimione (Atriplex) portulacoides salt marsh'(SM14); 'Juncus maritimus-Triglochin maritima salt marsh' (SM15); 'Festuca rubra salt marsh' or Juncetum gerardi (SM16); 'Artemisia maritima salt marsh' or Artemisietum maritimae (SM17); 'Suaeda vera-Limonium binervosum salt marsh' (SM21) of the north Norfolk coast; 'Halimione (Atriplex) portulacoides-Frankenia laevis salt marsh' (SM22); 'Spergularia marina-Puccinellia distans salt marsh' (SM23); 'Suaeda vera salt marsh' (SM25); 'Inula crithmoides on salt marshes' (SM26).

Adam 1981 described the vegetation of British salt marshes in terms of 49 'noda'. Salicornia occurred in 34 of these noda and in association with 44 other species of angiosperm, each of which occurred with a frequency greater than $81 \%$ in at least one of the 49 noda.

Salicornia can have an important role as a salt-marsh pioneer, as it is frequently the first higher plant to colonize intertidal mud and sand flats. Carey \& Oliver (1918) first described accretion around S. ramosissima plants to form ephemeral hummocks on a sand bank in the Bouche d'Erquy, Brittany, France. These, however, did not make a permanent contribution to the relief of the marsh, unlike those of the perennial Sarcocornia perennis. Salicornia species were the first colonists of sand flats after embankment removed tidal influence from the Grevelingen Estuary, in the Netherlands (Stienstra 1987). Direct observation of a naturally
Journal of Ecolo 89, 681-707 
690

A. J. Davy,

G. F. Bishop \&

C. S. B. Costa developing salt marsh in the macrotidal environment of the Severn Estuary, at Berrow, Somerset, UK, chronicled succession from bare sediment, through Salicornietum, to a species-poor Phragmitetum in fewer than 90 years (Willis 2000). Nevertheless, large stands of Salicornia on low-lying sand and mud flats may be ephemeral and do not necessarily initiate succession.

Salicornia spp. is the character-taxon of the class Thero-Salicornietea Tx. 1954; the order TheroSalicornietalia and alliance Thero-Salicornion Br.-Bl. 1933 em. Tx. 1950, whose eulittoral Salicornia-dominated communities extend from the north Atlantic and west Baltic coasts to the west coast of France and, locally, the coasts of Portugal and the north Mediterranean (Westhoff \& Schouten 1979). Ellenberg (1988) recognizes low-marsh, pure stands as Salicornietum dolichstachyae. In the same order, communities of the alliance Salicornion ramosissimae Tx. 1974 comprise swards of Puccinellia maritima with $S$. ramosissima at higher elevations (Ellenberg 1988). The inland saline area east of the Neusiedlersee in Austria supports Salicornietum prostratae Soó 1964, a rare community dominated by Salicornia prostrata (S. europaea agg.), with subdominant Puccinellia peisonis, Phragmites australis always present and sometimes with Suaeda pannonica present (Mucina et al. 1993). Bernatksy (1905) concluded that Salicornia was local and uncommon in halophytic communities of central Europe because seasonal fluctuations in water level were generally too wide. S. ramosissima is the dominant species of the Salicornietum europaeae hungaricum of Hungary (Soó 1960) and, in the Sarcocornio perennisSalicornietum ramosissimae, the Salicornia characteristic of coastal marshes in north-west Spain (Sánchez et al. 1996).

\section{Response to biotic factors}

The lower limit of Salicornia europaea on tidal mud flats at the seaward margin of salt marshes may be determined by bioturbation. Gerdol \& Hughes (1993), working in the estuary of the River Crouch, Essex, found that this lower limit corresponded with the upper limit of the abundant amphipod Corophium volutator (Pallas), at approximately mean high water neap tide level (MHWNT). Seedlings transplanted below this level were disturbed by the activity of Corophium but those in areas treated with insecticide to remove the Corophium had a doubled survivorship, similar to that of seedlings transplanted above MHWNT. The populations of Corophium of up to about $14000 \mathrm{~m}^{-2}$ were effectively able to prevent seedling establishment.

There are varied biotic relationships between Salicornia and algae on lower marshes. Algal mats (of Enteromorpha linza, E. torta, E. prolifera, Rhizoclonium riparium and Ulothrix speciosa) may contribute to mortality of Salicornia seedlings by pulling them from the sediment as the mats float on the incoming tide, as at Skallingen, Denmark (Jensen \& Jefferies 1984).
Costa (1992) found that patches colonized by Fucus vesiculosus ecad muscoides provided favourable sites for the trapping and germination of seeds of Salicornia. Mortality rates of seedlings of S. europaea were reduced in the algal patches. Temperatures inside Fucus patches were $2-4{ }^{\circ} \mathrm{C}$ lower than on the adjacent mud surface on sunny spring days (Costa 1992); fucoid algae intertwined with Salicornia may reduce evaporation and maintain salt concentrations closer to that of sea water (Chapman 1960). Salicornia plants themselves may facilitate colonization by dominant, perennial halophytes in physically stressful mid- and upper marshes, by reducing evaporation from the sediment surface and limiting salinity stress (Hacker \& Bertness 1999).

A study of neighbourhood effects in mixed stands of the annuals S. europaea and Suaeda maritima at Stiffkey, Norfolk, by Costa (1992) demonstrated that their coexistence was maintained mainly by the earlier germination of the smaller-seeded, slower-growing Salicornia and its consequent pre-emption of resources; when germinated at the same time, Salicornia was a poor competitor with Suaeda. Particularly in the low marshes of south-east England, large areas previously dominated by Salicornia have been invaded and replaced by Spartina anglica. According to Ball \& Brown (1970), Salicornia europaea is better able than $S$. dolichostachya to withstand competition from the perennial grasses Spartina anglica and Puccinellia maritima.

Greater species diversity and increased trophic complexity of upper marshes can lead to complex biotic interactions. Proudfoot (1993) investigated a 4-species interaction close to creek banks dominated by the shrubby perennial Atriplex portulacoides. The microlepidopteran Coleophora atriplicis (Meyrick) has successive instars of case-bearing larvae that feed on salt-marsh chenopods; early in the summer larvae feed on pollen and flowers of Atriplex portulacoides but in late summer they may migrate to Suaeda maritima and Salicornia, where they mine and consume the developing seeds. Proudfoot (1993) showed that a cline of decreasing abundance of Suaeda away from creek banks was due to increasing competition from Salicornia; populations of Salicornia close to the Atriplex were depressed as a result of preferential seed predation by Coleophora larvae. Rand (1999), working on New England salt marshes, has recently shown that the presence of $S$. europaea had an adverse effect on the annual Atriplex patula; this effect was also mediated indirectly through a shared herbivore, in this case the chrysomelid beetle Erynephalamaritima. Mature stands of Salicornia and their seeds can be an important food resource for passerine birds and geese (see IX A). On salt marshes in northern Germany, intense sheep grazing promoted communities containing $S$. europaea and its population density decreased after reduction of the grazing intensity, as Festuca rubra and other more competitive perennials replaced Puccinellia maritima (Kiehl et al. 1996).

Mats of tidal detritus deposited by high tides may remain long enough to kill the vegetation and create
Journal of Ecology, 89, 681-707 
Salicornia L.

bare patches in which Salicornia stands can become established (Truscott 1978). Experimental burial with wrack (tidal litter) of Spartina alterniflora (using a 5$10 \mathrm{~cm}$ thick layer) favoured germination and establishment of S. europaea on a Rhode Island Spartina patens marsh (Brewer et al. 1998); the success of Salicornia after disturbance by wrack burial was attributed to its ability to compete with Juncus gerardii under the more saline conditions of exposed sediments that are subject to high rates of evaporation. Here, S. europaea is regarded as a fugitive species of hypersaline bare patches and pans, because of its inability to compete with the dominant perennials (Bertness et al. 1992).

\section{Responses to the environment}

\section{(A) GREGARIOUSNESS}

Salicornia is generally highly gregarious but local distributions may be random or aggregated (Brereton 1971; Joenje 1978). Seedling population densities may be greater than $100000 \mathrm{~m}^{-2}$ in suitable habitats. Very local high-density clumps may occur where senescing mother plants have fallen over and been incorporated into surface sediments, releasing their embedded seed complements in situ as they decompose. Algal patches may also trap seeds and increase local density. Population density varies greatly, with the potential for strong regulation from a combination of negatively densitydependent seed production and density-independent seedling mortality (Jefferies et al. 1981; Davy \& Smith 1985, 1988; Smith 1985; Watkinson \& Davy 1985). The effects of density on seed production arise from the great morphological plasticity: at high density, individuals are unbranched with a single, terminal spike that can produce only a few seeds; at low density, the 3-dimensional branching structure can result in large individuals with hundreds of fertile terminal spikes (see VIII C). Watkinson \& Davy (1985) modelled the relationship between the reproductive output per plant $\left(N_{s} / N\right)$ and the density of surviving plants $(N)$ as:

$N_{\mathrm{s}} / N=\lambda(1+a N)^{-b}$ where $\lambda$ is the number of seeds produced by an isolated plant, $a$ is the area required to produce $\lambda$ seeds and $b$ describes the effectiveness with which resources are taken up from a given area.

Mortality tends to be of the Deevey type I pattern, preponderantly before flowering (Jefferies et al. 1981; Beeftink 1985). The mortality in young plants at high density is largely independent of density, resulting mainly from disturbance, herbivory, interspecific competition and water stress (Jefferies et al. 1981; McGraw \& Ungar 1981; Ellison 1987a; Ungar 1987a). Even at the highest densities found in the field $\left(>10000 \mathrm{~m}^{-2}\right)$, populations of $S$. europaea agg. show little evidence of self-thinning, despite closely approaching combinations

(C) 2001 British Ecological Society, Journal of Ecology, 89, 681-707 of mass and density where thinning would normally be predicted, according to the $-3 / 2$ power rule (Watkinson $\&$ Davy 1985). The fact that size inequalities within populations (expressed as Gini coefficients) did not change with density, or with growth during the season, is another manifestation of this (Ellison 1987b). The failure of Salicornia to self-thin may be explained in terms of growth geometry: because it lacks leaves and its stems branch sparsely, at high densities its biomass per unit area tends to increase as a linear function with height, rather than as the cubic function that describes more conventional morphology and which is believed to underlie the $-3 / 2$ self-thinning rule (Ellison 1987b, 1989).

Harley \& Bertness (1996) found that plants in crowded stands of $S$. europaea on a New England salt marsh were thinner and more susceptible to breakage, becoming dependent on their neighbours for mechanical support. The breaking force for individuals that had developed in isolation was much greater than for those in crowded stands; all individuals from crowded stands had collapsed and fallen over one week after experimental removal of their neighbours.

\section{(B) PERFORMANCE IN VARIOUS HABITATS}

Salicornia is confined to saline habitats and, as an annual, its performance is constrained by the length of the growing season. At its northern limit in the Canadian Arctic, where the growing season is effectively only 3 months and conditions are generally severe, individuals reach a height of $1-10 \mathrm{~cm}$ and produce simple branches only at the cotyledonary node, if at all (Wolff \& Jefferies 1987b). In such marginal habitats, plants colonize north-facing slopes poorly, where they do not branch and can ripen little seed; most of the populations are on south-facing slopes, where many individuals branch and seed is ripened reliably (Jefferies et al. 1983). In temperate latitudes, such as the salt marshes of north Norfolk, the growing season is typically $7-$ 8 months and under otherwise favourable conditions individuals can reach $40 \mathrm{~cm}$, with up to 4 th-order branching at the nodes. Such large individuals tend to occur in isolation, on nitrogen-rich drift lines of hyposaline estuarine marshes or on the sides of creeks in other relatively eutrophic marshes. Performance can be severely limited by summer hypersalinity in inland marshes and on the higher elevations of coastal marshes, especially at lower latitudes. The marshes and mangal of the Saudi Arabian Gulf coast potentially enjoy a 12-month growing season, allowing the development of massively branched individuals, with woody basal internodes $7 \mathrm{~mm}$ in diameter, that display a wide variety of morphologies; these plants can apparently persist for more than one year (Al-Turki 1992), despite their determinate growth. No seed dormancy has been detected in such populations and this is presumably an evolutionary response to a relatively benign and reliable environment (Al-Turki 1992).

There have been few reliable measurements of net primary production. Jefferies (1972) estimated the annual net productivity of Salicornia spp. on the marshes of the north Norfolk coast at $876 \mathrm{~g} \mathrm{~m}^{-2}$ year $^{-1}$, on the basis of frequent measurements of total standing 
692

A. J. Davy,

G. F. Bishop \&

C. S. B. Costa

crop. Similarly, annual net aerial primary production of $S$. ramosissima on the Cantabrian coast (north Spain) was estimated as $486 \mathrm{~g} \mathrm{~m}^{-2}$ year $^{-1}$ by Benito \& Onaindia (1991) using Smalley's method.

Species or populations characteristic of low marsh, where hypersalinity is unlikely and a moderate supply of nitrogen from seawater is assured (e.g. S. europaea and $S$. dolichostachya), tend to have faster growth rates than those of species abundant at higher elevations (e.g. S. ramosissima) (Jefferies 1977; Jefferies et al. 1981). There are numerous differences in demographic performance associated with the elevation of populations, or species, in the tidal frame (e.g. Beeftink 1985; Davy \& Smith 1985, 1988).

\section{(C) EFFECT OF FROST, DROUGHT ETC.}

Freezing is less of a hazard in the habitats generally affected by Salicornia than in non-saline habitats with the same climate, because of depression of the freezing point by high concentrations of solutes in both soils and plants. In addition, coastal locations are generally buffered, by proximity to the thermal capacity of the sea, from the lowest extremes of temperature experienced inland at similar latitude. Nevertheless, cohorts of seedlings that have germinated between December and March may be killed by exceptionally hard frosts on the north Norfolk coast; later germinating cohorts are rarely damaged. Seedlings may also be removed by ice scour. Autumn frosts hasten the senescence and collapse of plants, thus releasing the seeds into the sediment. The seeds overwintering in the surface sediments appear to be extremely tolerant of low temperatures, even those prevailing in the arctic. The annual distribution of frost is undoubtedly one of the determinants of the length of the growing season (cf. V B). As a halophyte, Salicornia is tolerant of exceptionally low water potentials in its root environment, whether they arise from salinity, drought or a combination of both (see V1 E).

Hydraulic forces generated by tidal flow, perhaps associated with scouring of the sediment and wave action, can be a major source of mortality for Salicornia seedlings at lower elevations on a salt marsh (Wiehe 1935). Salicornia is very susceptible to marine pollution from oil spills or refinery effluent and is killed quickly by a single spillage (Baker 1979). Salicornia ramosissima in a polluted estuarine marsh in south-west Spain accumulated high concentrations of $\mathrm{As}, \mathrm{Cr}, \mathrm{Cu}, \mathrm{Fe}$, $\mathrm{Mn}, \mathrm{Ni}, \mathrm{Pb}$, Ti and $\mathrm{Zn}$ without apparent harm (Luque et al. 1999).

\section{Structure and physiology}

\section{(A) MORPHOLOGY}

(C) 2001 British Ecological Society, Journal of Ecology, 89, 681-707
Each succulent, photosynthetic 'segment' is an internode separating consecutive pairs of oppositely arranged, but very reduced, leaves or scale leaves. In older, mainly basal, segments the outer tissues wither, leaving brown, non-succulent stems. The morphological nature of the photosynthetic tissue associated with each internode has been controversial. Fahn \& Arzee (1959) regarded it as entirely cortical in origin, attributing all photosynthesis to the stem. Duval-Jouve (1868) considered the outer cortex of each segment to be foliar in origin, a sheath being formed from the fused bases of the leaves immediately above. This 'foliar sheath' theory of the succulent cortex of Salicornia was given credence by de Fraine (1912) in a classical morphological study (using several species of Salicornia) on development at the shoot apex and of the vascular system. It was also supported by Halket (1928) after studying an abnormal plant of $S$. europaea in which the terminal parts of some leaves were clearly separated from the stem. Evidence from other succulent chenopods agrees (James \& Kyhos 1961).

The vascular anatomy of a segment is well known (de Fraine 1912; Fahn \& Arzee 1959; Ellison et al. 1993). A transverse section of the stem, taken mid-way within a segment, shows a central ring of eight primary vascular bundles enclosed by pericycle cells and an endodermis, or 'limiting layer', surrounded by a layer of water storage cells and then by a layer of photosynthetic cells. Between the inner (water storage) and outer (photosynthetic) layers lies vascular tissue originating at the distal end of the segment. Whilst it is agreed that this vascular tissue is foliar in origin, the true nature of the tissues it serves (water storing cells to the inside and photosynthetic cells towards the outside) is controversial: these non-vascular tissues are considered to be foliar by de Fraine (1912) but cortical by Fahn \& Arzee (1959). At each node, two of the eight vascular bundles diverge as leaf traces opposite each other. Each leaf trace divides into three: the central trace curves upwards to supply the much reduced leaf tip whilst the lateral pair curve downwards between the water storage and palisade layers of the foliar sheath or cortex to form a closed network of anastomosing vascular tissue (Fahn \& Arzee 1959). In curving downwards there is also effectively a rotation of each bundle of the lateral pair so that the phloem is outermost as in the leaf tip itself (de Fraine 1912). Above the node, two of the six surviving vascular bundles bifurcate, restoring the total to eight. Ellison et al. (1993) determined, by serial sectioning, changes in the mean diameters of vessel members of the primary vascular traces between consecutive nodes: hydraulic constrictions in $S$. europaea occur two nodes below the morphological emergence of a branch, differing in this respect from those in trees and palms.

The bulk of the mature stem originates from a secondary meristem immediately surrounding the system of primary bundles. Anomalous secondary thickening, widespread among members of the Chenopodiaceae, results in a concentric series of collateral vascular bundles embedded in a lignified ground tissue; the precise behaviour of the cambium during the formation of these bundles is disputed. The outer side of the vascular cambium is inactive except where it forms 
aerenchyma. Aerenchyma is present, particularly in $S$. europaea and S. ramosissima, in the lower regions of the stem and the upper part of the main root. It is surrounded by a thin layer of cork which is very readily torn off in cutting sections. In some cases aerenchyma of a special kind is present: the aerenchyma cells are drawn out at each end and appear to be covered with large 'pores' which are actually the result of cutting across tubular outgrowths connecting the loosely arranged cells (de Fraine 1912). Broad and short tracheid-like cells (Fahn \& Arzee 1959; Fahn 1974), 'stereids' and 'spiral cells' (de Fraine 1912) are found among the palisade cells in both vegetative and reproductive shoots. Their function is unknown and taxonomic significance uncertain (Ball \& Tutin 1959).

Among halophytes, S. europaea has an exceptionally high shoot to root (dry mass) ratio of about $10: 1$ (Cooper 1982). The root is diarch with a well marked endodermis and aerating tissue consisting of large intercellular spaces bridged by trabeculae. Although the presence of aerenchyma is generally associated with tolerance to flooding, in Salicornia this ability may be more related to superficial rooting and metabolic adaptations (Pearson \& Havill 1988). The root has anomalous secondary thickening, as in the stem.

Stomata are most numerous towards the distal end of segments. They are arranged with their long axes at right angles to the axis of the stem. A stomatal density of $49 \pm 2 \mathrm{~mm}^{-2}(n=30)$ has been recorded for S. europaea . Dalby (1962) measured stomatal volumes (calculated as that of a sphere from a diameter equal to that of the stoma length) ranging from 3 to $16 \times 10^{3} \mu^{3}$ in diploids to $8-39 \times 10^{3} \mu \mathrm{m}^{3}$ in tetraploids, with a changeover value around $13 \times 10^{3} \mu^{3}$ (= $29.17 \mu \mathrm{m}$ for length of stoma). Ball \& Brown (1970) reported the length of stomatal guard cells as (20-)24-28(-31) $\mu \mathrm{m}$ in $S$. europaea and (27-)29-36(-42) $\mu \mathrm{m}$ in $S$. dolichostachya.

Branching patterns are highly plastic and greatly affected by plant density; crowding reduces the degree of branching in both monospecific (Jefferies et al. 1981; Jensen \& Jefferies 1984; Smith 1985; Ellison \& Niklas 1988) and mixed (Costa 1992) stands. S. europaea s.1. growing early in a succession were bushy, profusely branched and the younger internodes were much shorter than older ones; plants in late succession were unbranched, etiolated and had internodes of equal size (Ellison \& Niklas 1988; see VI E).

There has been a plethora of morphometric studies of Salicornia (e.g. Langlois 1961a,b; Wilkon-Michalska 1985; Ungar 1987a), mainly in attempts to determine the morphological characteristics of subtaxa and local populations. Recent studies have applied numerical methods to morphometric data (Huiskes et al. 1985a; Ingrouille \& Pearson 1987; Ingrouille et al. 1990).

(C) 2001 British

Ecological Society, Journal of Ecology, 89, 681-707

\section{(B) MYCORRHIZA}

Endotrophic mycorrhiza in the roots of $S$. europaea ('S. herbacea') was first reported by Klecka \& Vukolov
(1937) in Czechoslovakia. Rozema et al. (1986) recorded between 0.1 and $1 \%$ colonization of root length with AM mycorrhiza in $S$. europaea ('S. brachystachya') on a Dutch middle marsh; $S$. dolichostachya on a low marsh showed $0.1-30 \%$ root colonization, external hyphae and a low incidence of spores. $S$. europaea at two inland salt marshes in north Germany had extensive root colonization (extra- and intraradical hyphae), with vesicles and arbuscules, whereas specimens from a marsh on the Baltic coast had only $3 \%$ colonization, with sparse vesicles and arbuscules (Hildebrandt et al. 2001). Spores present at high densities in soils at the inland sites were mainly identifiable as Glomus geosporum (Nicolson \& Gerdemann) Walker, using RFLP analysis of the ITS region of the rDNA of individual spores after amplification by PCR (Hildebrandt et al. 2001).

The main colonist of Salicornia at all elevations on Stiffkey salt marshes, Norfolk, is a previously unrecorded but distinct 'fine endophyte' AM fungus, possibly Glomus tenuis (Greenhall) Hall (Davy et al. 2000). It was also present in Aster tripolium, along with a conventional AM fungus.

\section{(C) PERENNATION: REPRODUCTION}

Therophyte. In Britain Salicornia is a summer annual that perennates entirely as a seed bank in salt marsh sediments. Seeds are shed between September and late November. The sediment seed bank therefore increases rapidly from a minimum in late summer to a maximum in December and January. More than $95 \%$ of seeds are concentrated in the upper $5 \mathrm{~mm}$ of the sediment. Mean seed bank maxima at various elevations on the marshes at Stiffkey range from 50000 to $100000 \mathrm{~m}^{-2}$, although local densities may be higher (Smith 1985; Davy \& Smith 1988). When shed, the seeds are mostly innately dormant but the proportion of dormant seeds declines to less than about $5 \%$ by February. The relatively few seeds that have not germinated by May have further dormancy enforced by increasing sediment salinity. In September, any seeds remaining after 1 year appear to have lost viability, as judged by tetrazolium vital staining. Similarly, there appears to be no significant persistence of seeds from one year to the next in Danish marshes (Jensen \& Jefferies 1984).

In contrast, persistent seed banks of $S$. europaea s.l. have been reported under more severe and less predictable conditions. Jefferies et al. (1983) found a seed bank in sediments of an arctic, coastal marsh, although the viability of the seeds was not certain. Substantial seed banks throughout the year, with a minimum of $38900 \mathrm{~m}^{-2}$ in August and a maximum of $128000 \mathrm{~m}^{-2}$ in November, were characteristic of an inland saline in Ohio, USA; in this population, which shows seed dimorphism (see VIII C, D), only the small (lateral) seeds persisted in the seed bank after the winter and this reserve played a significant role in maintaining the population in this highly stressful habitat (Ungar \& 
694

A. J. Davy,

G. F. Bishop \&

C. S. B. Costa

Riehl 1980; Philipupillai \& Ungar 1984; Ungar 1987a,b). The representation of $S$. europaea in the sediment seed bank may be disproportionately large in comparison with the species composition of the vegetation, especially in grazed marshes (Ungar \& Woodell 1996).

Lee et al. (1992) have developed a method of mass propagation of $S$. bigelovii clones by in vitro culture of shoot tips (in the presence of 1-naphthaleneacetic acid and $\mathrm{N}$-(phenylmethyl)-1H-purine-6-amine) that is useful in its development as a crop (see IX A) and for experimentation.

\section{(D) CHROMOSOMES}

The taxonomic intractability of Salicornia is reflected in the varied chromosome numbers reported for a range of taxa (Wulff 1936, 1937; König 1939; Ludwig 1950; Hambler 1954; Nannfeldt 1955; Ball \& Tutin 1959; Dalby 1962; Ferguson 1964a; Contandriopoulos 1968; Ball \& Brown 1970; Parriaud 1971; Castroviejo \& Coello 1980; Smith 1985; Wolff \& Jefferies 1987b; Al-Turki 1992). The basic chromosome number for the genus is $x=9$ and British material may be either diploid $(2 n=18)$ or tetraploid $(2 n=36)$. Aneuploid numbers reported by Wulff $(1936,1937)$ and Hambler (1954) are regarded as suspect (Dalby 1962). A triploid type $(2 n=27)$ has been reported from Italy (Cristofolini $\&$ Chiapella 1970). The chromosomes of Salicornia are small, ranging from about $0.6-1.8 \mu \mathrm{m}$ in length but with some variation in shape (Dalby 1962).

Recent systematic treatments (Ball \& Tutin 1959; Ball 1964; Ferguson 1964a,b; Ball \& Brown 1970; Dalby 1989; Stace 1997) use ploidy level in the delineation of species: $S$. pusilla, $S$. ramosissima and $S$. europaea s.s. are considered diploid and $S$. dolichostachya, S. fragilis and $S$. nitens are defined as tetraploid. Material from the field that is referred to $S$. europaea and S. ramosissima on morphological criteria cannot always be reconciled with this. Tetraploid types are more frequent than diploids in open, low marsh, pioneer situations (e.g. Ball \& Brown 1970). Upright forms more often tend to be diploid and prostrate forms more often tetraploid (e.g. Parriaud 1971).

Diploid and tetraploid cytotypes may differ in the size of pollen, stomatal guard cells and seeds (Dalby 1962), in fertile segment shape, number of fertile segments in the terminal spike, length of anthers (Ball $\&$ Brown 1970) and in the distance between the apex of the middle floret and the apex of the segment (Ingrouille et al. 1990).

\section{(E) PHYSIOLOGICAL DATA}

\section{Salinity tolerance}

(C) 2001 British Ecological Society, Journal of Ecology, 89, 681-707
As a halophyte, Salicornia is able to maintain low water potentials in its tissues by accumulating solutes. There are many reports of the accumulation of high concentrations of inorganic ions, mainly sodium and chloride in a variety of taxa (e.g. Albert 1975; Grouzis et al. 1977; Gorham et al. 1980; Cooper 1982; Riehl \& Ungar 1982; Ayala et al. 1996). Salicornia has a relatively high ratio of $\mathrm{Na}: \mathrm{K}$, typical of dicotyledonous halophytes (Gorham et al. 1980; Rozema 1991). These high concentrations of inorganic ions are accumulated predominantly in the cell vacuoles; there is some evidence that pinocytosis is instrumental in ion accumulation in the vacuoles of shoot cells (Kurkova \& Balnokin 1994). As in other halophytic chenopods, high concentrations of compatible organic solutes (mainly the form of the methylated quaternary ammonium compound, glycinebetaine) are maintained in the cytoplasm (Stewart et al. 1979; Gorham et al. 1980; Briens \& Larher 1982). This asymmetric distribution of solutes protects metabolic activity from the potentially toxic effects of high concentrations of inorganic ions.

Optimal growth generally occurs at external salinities equivalent to less than half that of seawater, depending on other environmental conditions. Halket (1915) first showed a response of growth to salt. Seedlings of $S$. ramosissima on intact sods taken from a salt marsh grew taller when watered with $1 \%$ sea-salt solution (equivalent to $c .170 \mathrm{~mm} \mathrm{NaCl}$ ) than when there was no salt or when concentrations were higher (2-5\%). In water culture, the greatest growth in height and branch length of $S$. dolichostachya ('S. oliveri Moss') was obtained in the presence of $2 \%(340 \mathrm{~mm}) \mathrm{NaCl}$; salt concentrations of $3-5 \%(520-860 \mathrm{~mm})$ were progressively detrimental to growth. Plants of this species grew very poorly and failed to flower when grown without salt. Langlois $(1967,1971$ a) found that a daily, 90 -minute immersion of seedlings of $S$. europaea ('S. stricta Dumort.') in nutrient solution containing $10 \mathrm{~g} \mathrm{~L}^{-1} \mathrm{NaCl}$ (170 mM) gave growth more similar to that seen in the field than treatments with no immersion or two immersions a day. Cooper (1982) reported that $S$. europaea gave its maximum yield in the saline treatments of growth experiments, applied as weekly waterings with $340 \mathrm{~mm} \mathrm{NaCl}$. The North American form S. bigelovii Torr. shows optimal growth at $200 \mathrm{~mm} \mathrm{NaCl}$ (Ayala et al. 1996). Even in vitro callus cultures of $S$. europaea have been reported to accrue dry mass maximally in the presence of $0.75-1.0 \%(129-170 \mathrm{~mm}) \mathrm{NaCl}$ (von Hedenström \& Breckle 1974), although it is not clear what proportion of this dry mass was accounted for by accumulation of inorganic salts. In a comparison of relative growth rates under standardized glasshouse conditions with 15 salt marsh species, Salicornia was amongst the most salt-tolerant, both under flooded and well-drained conditions (Rozema et al. 1985). Rozema, van der List et al. (1987) found that dry mass was increased in S. europaea ('S. brachystachya Meyer') and $S$. dolichostachya by treatment with $250 \mathrm{~mm} \mathrm{NaCl}$ on a clay substrate; however, growth was reduced by this salinity on a sandy substrate and $S$. dolichostachya was the more adversely affected.

The effects of salinity and inundation by seawater on different aspects of metabolism have been studied in 
various segregates of Salicornia: protein accumulation (Langlois 1969, 1971a), sugar movement (Langlois 1971b) and plasma-membrane ATPase activity (Ayala et al. 1996)

\section{Tolerance of flooding and sediment hypoxia}

As expected of plants that include forms capable of colonizing the lowest parts of tidal marshes, Salicornia is extremely tolerant of regular flooding. Nevertheless, growth of $S$. europaea is reduced by cultivation under continuous waterlogging, in comparison with free drainage at the same salinity (Brereton 1971; Cooper 1982). A combination of waterlogging and non-saline conditions results in very poor growth and survival (Cooper 1982; Keiffer et al. 1994).

Salicornia may avoid root hypoxia by relatively shallow rooting, despite poorly developed aerenchyma. Schat et al. (1987) found that experimental deoxygenation of the root environment reduced relative growth rate and the elongation rate of roots, but no effects were detected on $\mathrm{CO}_{2}$ exchange or inorganic nutrient uptake; neither was there any difference in response between $S$. dolichostachya from the lower marsh and $S$. ramosissima from the upper marsh. Nevertheless Salicornia is tolerant of toxic reduced substances resulting from chemical transitions at low sediment redox potentials, including those of sulphate to sulphide and manganic to manganous ions. Ingold \& Havill (1984) found that the addition of $100 \mu \mathrm{m}$ sulphide to a sealed water-culture system did not have an adverse effect on the growth and root development of S. europaea, unlike three other salt marsh species examined; $S$. europaea was also the only vascular plant rooted in sulphidecontaining sediments on a lower marsh. Havill et al. (1985) similarly did not detect any adverse effects of this concentration of sulphide on its growth and metabolism. Experiments by van Diggelen et al. (1987) indicate that the growth of neither S. europaea ('S. brachystachya') nor $S$. dolichostachya from The Netherlands was affected by sulphide concentrations of up to $500 \mu \mathrm{M}$. On the other hand, Pearson \& Havill (1988) were able to distinguish between the responses of the species: root alcohol dehydrogenase (ADH) activity of $S$. europaea was little affected by culture in sulphidecontaining $(100 \mu \mathrm{M})$ nutrient solution, whereas the corresponding ADH activities of $S$. dolichostachya and $S$. fragilis were increased more than 7- and 14-fold, respectively, compared with non-sulphide treated controls.

Similarly, S. europaea was the most tolerant, of eight salt marsh halophytes examined, to $\mathrm{Mn}^{2+}$ in saline culture solution, its growth being unaffected up to a concentration of $10 \mathrm{~mm}$ (Cooper 1984). Presumably high concentrations of $\mathrm{Na}^{+}$ameliorate the toxicity of $\mathrm{Mn}^{2+}$, because Singer \& Havill (1985) reported that root and shoot growth was inhibited by concentrations above $0.5 \mathrm{~mm} \mathrm{Mn}^{2+}$ after 6 weeks in Hoagland (nonsaline) culture solution.

\section{Water relations}

Water is conserved by low transpirational losses associated with the absence of leaves and is stored in succulent tissues. The water content of stems (succulence) varies with external conditions; that in $S$. europaea ('S. stricta') main stems in the Orne estuary of northern France ranged from about $700-1100 \%$ of dry mass (Langlois 1968a). Likewise, tissue water potentials depend on external salinity and the accumulation of solutes through osmoregulation but they can become very low without resulting in death. Langlois (1968a) recorded solute (osmotic) potentials no lower than 2.67 MPa for S. europaea in the Orne estuary. Material from a coastal salt marsh at Seal Beach, California had a water potential $\left(\psi_{w}\right)$ of $-4.23 \pm 0.24 \mathrm{MPa}$, with a component solute potential $\left(\psi_{\mathrm{s}}\right)$ of $-5.32 \pm 0.10 \mathrm{MPa}$ (Kuramoto \& Brest 1979). Tsuda (1961) reported an extreme solute potential of expressed sap as $-7.6 \mathrm{MPa}$, with sodium chloride content contributing $-7.2 \mathrm{MPa}$ of this, under extremely hypersaline conditions in Japan. Riehl \& Ungar (1982) recorded midsummer tissue $\psi_{w}$ as low as $-9 \mathrm{MPa}$ in an inland saline in Ohio, USA. Momonoki \& Kamirura (1994) reported an increase in the osmolality of stem and branch sap from about $650 \mathrm{mOsm} \mathrm{kg}{ }^{-1}-2600 \mathrm{mOsm} \mathrm{kg} \mathrm{m}^{-1}$ (approximately equivalent to $\psi_{w}$ of -3 to $-13 \mathrm{MPa}$ ) during the growing season, in plants growing at the edge of Lake Notoro-ko, Japan. The $\mathrm{NaCl}$ concentration required for incipient plasmolysis of epidermal cells rose from 1.6 to $2.2 \%$ during the growing season (Momonoki et al. 1994) and these values were high in comparison with other halophytes. Rozema, van der List et al. (1987) detected a diurnal cycle in $S$. europaea (' $S$. brachystachya'), with $2.7 \%$ increase in stem thickness during the dark and shrinkage during the day.

\section{Gas exchange}

As expected, stomatal conductance decreased with increasing external salinity in S. bigelovii, producing a concomitant decrease in the rate of transpiration (Ayala \& O'Leary 1995). Carbon dioxide fixation is by the $\mathrm{C} 3$ pathway, with a $\partial^{13} \mathrm{C}$ ratio of -26.62 determined for S. europaea (Carolin et al. 1982). Guy et al. (1986) reported a range of $\partial^{13} \mathrm{C}$ ratio $(-29$ to -23$)$ in $S$. rubra ( $S$. europaea ssp. rubra), with less negative values at higher salinity reflecting differences in long-term wateruse efficiency. Low activities of PEP carboxylase, without fluctuations due to endogenous rhythms, have been reported (Kuramoto \& Brest 1979). Net photosynthetic rates have been shown to decrease slowly with lowering of external water potential; $\mathrm{CO}_{2}$ uptake in the absence of salt was $7.59 \pm 0.64 \mathrm{mg} \mathrm{dm}^{-2} \mathrm{~h}^{-1}$ on a leaf area basis (14.22 $\pm 1.66 \mathrm{mg} \mathrm{g}^{-1} \mathrm{~h}^{-1}$ on a dry mass basis) and this was reduced to $4.75 \pm 0.12 \mathrm{mg} \mathrm{dm}^{-2} \mathrm{~h}^{-1}$ $\left(8.47 \pm 1.30 \mathrm{mg} \mathrm{g}^{-1} \mathrm{~h}^{-1}\right)$ after equilibration for $72 \mathrm{~h}$ at seawater salinity (Kuramoto \& Brest 1979). Dark respiration declined similarly. Schat et al. (1987) found
Ecological Society, Journal of Ecology, 89, 681-707 
696

A. J. Davy,

G. F. Bishop \&

C. S. B. Costa that net photosynthetic and dark respiration rates (on a fresh mass basis) declined with increasing plant fresh mass. They also observed mid-day stomatal closure, exceptionally, in certain individuals of S. ramosissima under hypoxic stress.

\section{Response to inorganic nutrients}

Salicornia plants growing on salt-marsh sediments, in situ or on cores removed for experiments, typically respond to additions of nitrogen and phosphorus only in the absence of significant competition from perennial species (e.g., Pigott 1969). In sand culture, growth of $S$. europaea and $S$. ramosissima responds to increasing nitrate concentration up to at least $1 \mathrm{~mm}$ (Jefferies 1977). Addition of inorganic nitrogen and phosphorus to lower marsh plots on the north Norfolk coast significantly increased shoot frequency over 5 years but did not have any effect on higher marsh plots; at the end of the experiment there was significantly greater Salicornia biomass in nutrient treated lower-marsh plots, particularly those that had received nitrate (Jefferies \& Perkins 1977). Regular additions of nitrate- or ammonium-N within a single growing season can markedly stimulate biomass accumulation and, especially, seed production (Jefferies et al. 1979). Similarly, at the limits of its distribution on the shores of Hudson Bay, seed production of $S$. europaea agg. was increased greatly by experimental addition of sodium nitrate (Jefferies et al. 1983). $S$. europaea demonstrated the ability to accumulate nitrogen with increasing external nitrate availability (Costa 1992). Total concentrations of $\mathrm{N}$ in shoots of S. dolichostachya range from 1.0 to $1.35 \%$ (dry mass) in the field (Pigott 1969) to 6.5\% in nitrogen-rich hydroponic culture (Schat et al. 1987).

\section{Induction of flowering}

The conditions that promote flowering are poorly understood. In cultivation, plants typically flower precociously at a few weeks old, thus terminating vegetative growth and limiting the capacity for seed production. Langlois (1968b) suggests that the high radiant flux densities found in its natural environment are necessary to prevent precocious flowering. S. europaea plants from both Britain (Costa 1992) and the Netherlands (Joenje 1978) have shown a minimum threshold size for successful seed production. This can lead to oscillatory population dynamics where increasing numbers of individuals fail to reach the threshold size as density increases or environmental factors limit growth.

\section{Response to shade}

Growth and branching vary enormously, depending on population density (especially at low elevation in marsh zonation, or in early successional sites) and the presence of other species (especially higher in the zonation, or in later successional sites). Branching responses appear to be mediated substantially by light availability. A computer simulation of the 3-dimensional branching patterns in $S$. europaea generated forms that corresponded well with those found at different stages in a salt marsh succession, by simultaneously maximizing light interception and minimizing total bending moment (Ellison \& Niklas 1988).

\section{(F) BIOCHEMICAL DATA}

The distinctive violet-red colouration of many forms of Salicornia is mainly due to the presence of a betacyanin pigment, betanidin-5-O-[2-O-( $\beta$-Dglucopyranosyl uronic acid)]- $\beta$-D-glucopyranoside (Chiji 1976). The reddish stems of S. europaea also contain two 2,3-unsubstituted chromones, identified as 6,7-methylenedioxychromone and 6,7-dimethoxychromone, respectively (Chiji et al. 1978; Arakawa et al. 1983). Arakawa et al. (1982) determined the structure of two new isoflavones ( 2 '-hydroxy-6, 7-methylenedioxyisoflavone and 2', 7-dihydroxy-6-methoxyisoflavone) and one flavanone (-)-(2S)-2'-hydroxy-6, 7-methylenedioxyflavanone, from $S$. europaea in Japan. Geslin \& Verbist (1985) found that flavonoids represent $1.2 \%$ of the dry mass of S. europaea and isolated eight flavonoids, of which the most abundant was (malonyl- 6 " $\beta$ D-glucoside)-3-quercetol. Borkowski \& Drost (1965) identified two distinctive alkaloids from $S$. europaea ('S. herbacea'), salicornin and saliherbin.

Weete et al. (1970) found differences between shoot, root and seed tissues of $S$. bigelovii in the relative distribution of paraffin hydrocarbons (chain lengths $\mathrm{C}_{21}$ to $\mathrm{C}_{33}$ ) and total fatty acids (chain lengths $\mathrm{C}_{14}$ to $\mathrm{C}_{24}$ ); there were also substantial differences between two populations in both hydrocarbons and fatty acids. Salicornia europaea seeds are rich in oil, containing $26-30 \%$ total lipids; the di-unsaturated linoleic acid accounted for $70 \%$ of the fatty acid content (Austenfeld 1986, 1988). Seed oil of Salicornia (SOS-7), a form selected for cultivation as an oil-seed crop, has been analysed in great detail (El-Shami \& El-Negoumy 1993; El-Mallah et al. 1994). Its fatty acid composition is likewise dominated by linoleic acid (66.9\%), with $17.5 \%$ oleic acid, only $1.4 \%$ linolenic acid and traces of stearic and palmitic acid; 22 different triglycerides were detected by HPLC. In common with other members of the Chenopodiaceae, the photosynthetic tissues of Salicornia contain a remarkable diversity of sterol biosynthetic capacity. Eight different $24-\alpha$-ethylsterols have been identified, with spinasterol and stigmasterol most abundant; S. europaea apparently differs from $S$. bigelovii in lacking isofucosterol (Salt \& Adler 1985). According to ElMallah et al. (1994) the seeds of SOS-7 also contain a range of tocopherols (mainly alpha and gamma), sterols (mainly 7-stigmastenol and sitosterol) and sterylglycosides (mainly B-sitosterol and campestigmasterol).

Hagène (1958) reported that early in the growing season, the ascorbic acid content of S. pusilla (' $S$. disarticulata') was consistent at about $250 \mathrm{mg} 100 \mathrm{~g}^{-1}$ but
Journal of Ecolt 89, 681-707 
in the autumn the concentration was correlated with the total hours of sunshine on the day of collection and the previous two or three days. The cell walls of S. ramosissima are rich in arabinose, galacturonic acid, glucose and proteins, and contain $0.7 \%$ ferulic acid and $3.8 \%$ acetic acid (Renard et al. 1993).

Ion transport within Salicornia at nodes and at the parting points of lateral roots from the main stem may be facilitated by acetylcholinesterase activity (Momonoki et al. 1996). There are several reports of the distributions of ions and elements in different tissues and organs of S. europaea agg. (Gorham et al. 1980; Austenfeld 1986).

Nitrogen content depends on the material, its age and environmental conditions (Langlois \& Ungar 1976). Under various submergence treatments, main stems and branches of young plants of inland origin (referred to S. ramosissima) accumulated total $\mathrm{N}$ of $3.0-4.3 \%$ (dry mass), representing $1.8-3.0 \%$ as protein $\mathrm{N}$ and $1.0-2.1 \%$ as soluble N; corresponding values for $S$. europaea ('S. stricta Dumort.') of coastal origin were total N $4.7-5.5 \%$, protein $\mathrm{N} 1.0-4.7 \%$ and soluble $\mathrm{N} 0.4-$ $4.5 \%$. Mature plants had generally lower nitrogen concentrations. Patterns of serological and electrophoretic variation in seed proteins (Cristofolini 1968; Cristofolini \& Chiapella 1970) in 13 Italian populations corresponded neither with each other nor with those for morphology or geographical and ecological distributions. Schat et al. (1987) reported total phosphorus concentrations equivalent to $0.51-0.53 \%$ (dry mass) for $S$. ramosissima and $0.42-0.59 \%$ for $S$. dolichostachya.

\section{Phenology}

The life cycle of Salicornia is typically summer-annual, although in subtropical environments plants can persist for more than a year. Germination tends to coincide with low sediment salinities, in winter in Britain (Smith 1985) and from February to June in Ohio salt pans (Ungar et al. 1979). The germination period can be protracted in mild winters: at Stiffkey in Norfolk, seedlings are occasionally found as early as November but are most abundant from early January to late April. Characteristically lower-marsh populations, such as $S$. dolichostachya and $S$. europaea, tend to germinate earlier than upper marsh ones, e.g. S. ramosissima and S. pusilla (Jefferies et al. 1981; Smith 1985).

Vegetative growth proceeds by the addition of new stem segments and, except at very high population densities, lateral branches develop. In lower marsh populations growth is usually continuous, whereas higher marsh populations often show slow growth in the period when hypersaline conditions can occur, when spring tides fail to cover the marsh surface around the summer solstice. In late July or August, vegetative growth is terminated by the production of fertile segments at the ends of all branches. Benito \& Onaindia (1991) found that the standing crop of $S$. ramosissima peaked in early September in a Cantabrian salt marsh (north Spain); the highest rate of increase in standing live crop was in July.

In Britain, flowering occurs mainly from mid-August to mid-September but flowers may be seen from late July until well into October. Salicornia europaea ('S. stricta')type flowers a fortnight earlier than $S$. ramosissima-type (Dalby 1955). Populations flower first on the seaward edge of the marsh at Stiffkey, Norfolk, where S. dolichostachya flowers earliest; $S$. pusilla, found characteristically on the drier, upper interfluves, is the last to flower (Smith 1985). Neotenous flowering of plants has been observed by Langlois (1968b) in S. europaea ('S. stricta') grown in artificial culture. Seeds reach maturity from midSeptember onwards and fall out of the dead or dying parent plant although some may remain in situ for germination the following spring (Ball \& Brown 1970).

\section{Floral and seed characters}

\section{(A) FLORAL BIOLOGY}

Flowers are normally bisexual but plants in the field or in cultivation may exceptionally have unisexual flowers as a result of male or female organs failing to develop (Ferguson 1964b). Some populations are undoubtedly cleistogamous, their anthers dehiscing before exsertion, or failing to exsert (e.g. Ball \& Tutin 1959). Chasmogamous flowers are usually weakly protogynous but the stigmas are persistent and often seen in contact with dehiscing anthers such that self pollination is easily possible (Knuth, Poll. 3) and is probably the norm (Dalby 1962; Ferguson 1964b). Pollen may also fall onto the stigmas of flowers immediately below on the same plant. Ferguson (1964b) found that in tetraploid plants resembling $S$. lutescens and $S$. dolichostachya, both in the field and in cultivation, either the stigmas protruded just before the undehisced anthers were exserted or the anthers and stigmas emerged together.

The pollen grains are almost spherical, differing from other chenopodiaceous pollen only in size and details of sculpturing (Al-Turki 1992). Dalby (1962) detected large quantities of wind-borne chenopodiaceous pollen under circumstances where it is reasonable to assume that it must have come from Salicornia. This indicates that outbreeding is potentially possible. Pollen grain diameter in $S$. europaea is (20-)24-28(-31) $\mu \mathrm{m}$; in S. dolichostachya it is (27-)31-34(-42) $\mu \mathrm{m}$ (Ball \& Brown 1970). Dalby (1962) recorded smaller pollen-grain volumes in diploids $\left(2-12 \times 1000 \mu^{3}\right)$ than in tetraploids $\left(6-19 \times 1000 \mu^{3}\right)$ with the changeover at c. $10.5 \times 1000 \mu \mathrm{m}^{3}$ (= 27.2 $\mu \mathrm{m}$ diameter). By mounting fresh pollen grains in acetocarmine and considering those which took up the stain deeply to be fertile, 90 $100 \%$ of pollen grains were generally found to be fertile, whether taken from diploid or tetraploid individuals. Some tetraploid individuals showed exceptionally low pollen fertility.
Ecological Society, Journal of Ecology, 89, 681-707 
698

A. J. Davy,

G. F. Bishop \&

C. S. B. Costa

'Bagging' experiments with plants on several British salt marshes have demonstrated self compatibility, with only a slight depression of seed-set associated with enclosure of the shoots in polythene bags (Dalby 1962). There is no evidence of apomixis. Excision of the stigmas from protogynous flowers of S. europaea resulted in failure to set seed in 16 flowers out of 17; the single seed set may have resulted from pollination before excision of the stigma (Dalby 1962).

Despite a capacity for wind pollination, the floral biology of Salicornia apparently favours the production of inbred lines, which may be regarded as microspecies or locally differentiated populations, with gene exchange at low frequency between them. Noble et al. (1992) typed the nuclear rDNA (using RFLP analysis) in 38 maternal plants from Stiffkey in Norfolk and 2112 of their progeny and found no instance of progeny differing from their maternal type. The method was capable of discriminating $1 \%$ of a different DNA type within a sample and so any out-breeding must have been at a lower frequency than $1 \%$. This strong tendency to inbreeding undoubtedly contributes to the taxonomic complexity of the group.

\section{(B) HYBRIDS}

Uncertainty regarding the delimitation of species within Salicornia makes the identification of hybrids even more uncertain. A putative hybrid $S$. pusilla $\times$ $S$. ramosissima has cymes with different numbers of flowers (1, 2 or 3 ) on the same individual (Hyb. Br. Isl.). Such plants are not uncommon on the higher parts of the salt marsh at Stiffkey, Norfolk. Four other putative crosses from British material are listed by Stace (Hyb. Br. Isl.).

\section{(C) SEED PRODUCTION AND DISPERSAL}

A fertile segment produces a maximum of 6 seeds ( 2 cymes with 3 flowers each), except in S. pusilla, where only 2 seeds per fertile segment can be produced. The fecundity of individual plants is strongly and negatively density-dependent, as it reflects the highly plastic number and the length of fertile branches produced. Hence seed production per unit ground area may remain approximately constant over a 20 -fold range of plant density, or greater. Plants at very high density, with a single fertile segment, may produce 6 seeds or fewer; isolated individuals potentially may produce more than 1000, depending on growth conditions. At typical field densities (300-30000 $\mathrm{m}^{-2}$ mature plants) between 300 and 10 seeds may be produced on average per individual (Jefferies et al. 1981; Jensen \& Jefferies 1984; Smith 1985; Davy \& Smith 1988).

The proportion of flowers that set seed declines at

(C) 2001 British Ecological Society, Journal of Ecology, 89, 681-707 high density but individual seed mass can increase with the resulting redistribution of resources (Smith 1985). Dalby (1962) reported that diploids tend to have smaller seeds $(1-1.8 \mathrm{~mm})$ than tetraploids $(1.2-2.7 \mathrm{~mm})$ and this has been supported by comparisons of particular taxa: S. ramosissima ('S. appressa Dumort.') has smaller seeds than $S$. fragilis ('S. stricta Dumort.') on the Normandy coast of France (Binet \& Langlois 1962); S. europaea ('S. brachystachya Meyer') has smaller seeds than S. nitens ('S. emerici Duval-Jouve') on the Mediterranean coast of France (Knoerr 1968) and $S$. europaea has smaller seeds $(1.0-1.7 \mathrm{~mm})$ than S. dolichostachya $(1.5-2.3 \mathrm{~mm})$ in the Dee Estuary (Ball \& Brown 1970).

Similarly, within cymes the mean mass of central (median) seeds is greater than that of the lateral ones (König 1960; Dalby 1962; Ungar 1979). The magnitude of this seed dimorphism is extremely variable. In a range of nine populations from the north Norfolk coast, Smith (1985) found mean masses of central (median) seeds of $0.25-0.57 \mathrm{mg}$ and corresponding mean masses of lateral seeds of $0.20-0.50 \mathrm{mg}$; only $S$. dolichostachya did not have significantly heavier central seeds. In contrast, Ungar (1979) found that in North American $S$. europaea the central seeds $(0.78 \pm 0.1 \mathrm{mg})$ and the lateral ones $(0.24 \pm 0.4 \mathrm{mg})$ did not overlap in mass range. The composition (see VI F) as well as the concentration of nutrient reserves is the same in both small, lateral (mean air-dry mass $0.25 \pm 0.01 \mathrm{mg}$ ) and large, median (mean air-dry mass $0.31 \pm 0.01 \mathrm{mg}$ ) seeds of $S$. europaea (Austenfeld 1988).

Approximately $50 \%$ of the seeds fall within $100 \mathrm{~mm}$ of the parent plants (Ellison 1987b) but small, fairly consistent numbers spread up to $400 \mathrm{~mm}$ and a few can disperse considerable distances (Smith 1985). Rand (2000) found that numbers of S. europaea seeds caught by sticky traps correlated well with the sizes of the corresponding germinable seed banks, at sites of different elevations across a New England salt marsh. Separate Salicornia seeds have little buoyancy. Hilton (1975) reported that fresh seeds of $S$. dolichostachya sank immediately and air-dried seeds sank within a few minutes; sinking rates in seawater at $9{ }^{\circ} \mathrm{C}$ were $12.5-$ $15 \mathrm{~mm} \mathrm{~s}^{-1}$. Koutstaal et al. (1987) reported that $50 \%$ of Salicornia seeds sank within $2 \mathrm{~h}$ and all sank within a day. Submerged seeds may be rolled along the sediment surface by tidal currents but are apt to be trapped by depressions, sessile algae and perennial vegetation (Brereton 1971; Hilton 1975; Costa 1992). The testa is covered with mucilaginous and hooked hairs (Fig. 9), which assist in anchoring the seed to the sediment surface. Germinating seedlings that do not establish immediately are buoyed up by the expanding cotyledons (Petch \& Swann 1968) and are likely to be carried away by tidal currents. Floating seedlings of $S$. dolichostachya can remain alive, without further growth, and able to establish for up to 3 months; this provides a potential for long-distance transport not afforded by ungerminated, shed seeds (Hilton 1975). In S. pusilla the disarticulated fertile segments retain their seeds and may float in sea water for 3 months (Dalby 1963); they are characteristically deposited on high points and the strand line 
Salicornia L.
(C) 2001 British Ecological Society, Journal of Ecology, 89, 681-707 (a)

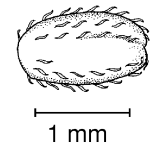

(c)

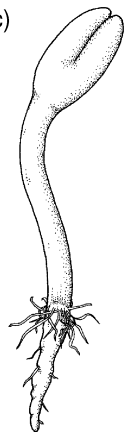

(b)

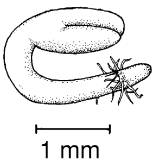

(d)

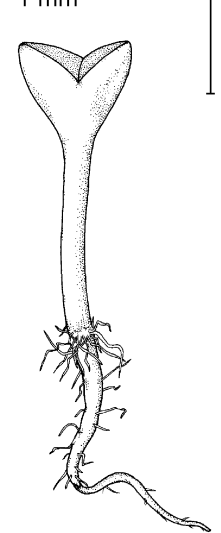

(e)
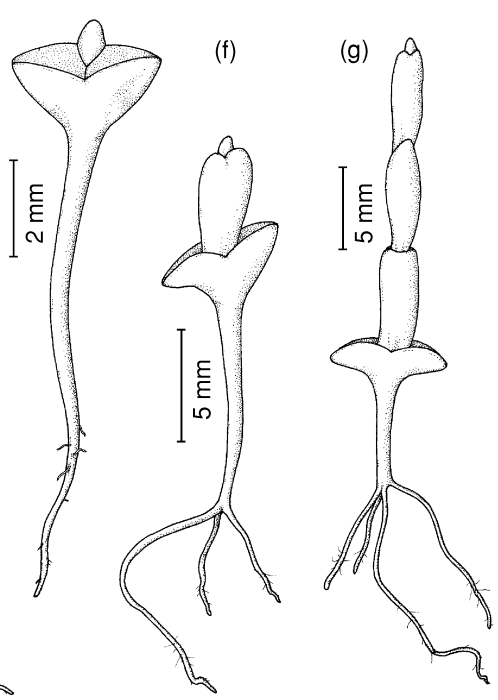

Fig. 9 Germination and seedling development in Salicornia europaea agg. (a) seed, (b) germination, and (c-g) developing seedling.

where the seeds germinate in situ. The central seeds of dimorphic $S$. europaea (S. patula) found in Mediterranean environments are dispersed attached to a persistent perianth, which also aids buoyancy (Berger 1985). Such floating seeds have also been noted in Norfolk, UK (Petch \& Swann 1968).

\section{(D) VIABILITY OF SEEDS: GERMINATION}

The germinability of Salicornia seeds is generally high: collections from diverse populations have achieved $90-100 \%$ germination within a few days under laboratory conditions (Langlois 1961b; Smith 1985; Al-Turki 1992). Viability has been reported to be high after several weeks of dry storage at room temperature (Langlois 1961b; Al-Turki 1992), although this is not a realistic simulation of over-wintering conditions in British salt marshes. On salt marshes in north Norfolk seeds released into the sediment seed bank early in the autumn tend to be innately dormant. This dormancy can be broken by up to 5 weeks of chilling at $c .3{ }^{\circ} \mathrm{C}$ in the imbibed state, which promotes both the amount and rate of germination; seeds released later in the autumn require less chilling, suggesting that the requirement has been fulfilled partially by declining field temperatures (Smith 1985). Cold stratification to relieve seed dormancy has been widely reported in populations of Salicornia species (Langlois 1966; Grouzis 1973; Grouzis et al. 1976; Ungar 1977). Air-drying of fresh seed and pre-treatment with high salinity (equivalent to seawater) may also break dormancy (Smith 1985; Huiskes et al. 1985b; Keiffer \& Ungar 1997).

Once the requirements for breaking dormancy have been satisfied, diurnally fluctuating temperature regimes between $5 / 15$ and $20 / 30{ }^{\circ} \mathrm{C}$ appear to have little effect on overall germination but germination is faster at higher temperatures (Huiskes et al. 1985b; Smith 1985; Al-Turki 1992). Continuous low temperatures inhibit germination (Huiskes et al. 1985b), which leads to conditional dormancy in the field in winter. Light appears to stimulate germination, at least in certain populations of $S$. dolichostachya ('S. emerici'), S. pusilla ('S. disarticulata') and $S$. europaea ('S. patula' and 'S. stricta') (Langlois 1966; Grouzis et al. 1976; Berger 1985). Salicornia seeds, like those of most halophytes (Ungar 1978), germinate best at low salinity: Langlois (1961b, 1966) recorded up to $100 \%$ germination in rainwater and Lötschert (1970) reported that S. europaea ('S. stricta ssp. typica') germinated best in pure water; Grouzis (1973) found progressive inhibition in S. dolichostachya ('S. emerici') with increasing salinity, starting from $c .8 .5 \mathrm{~mm} \mathrm{NaCl}$; Berger (1985) reported an optimum salinity of $34 \mathrm{~mm} \mathrm{NaCl}$ in ' $S$. patula', whereas Huiskes et al. (1985b) and Smith (1985) independently found very similar germination at 0 and c. $50 \mathrm{~mm} \mathrm{NaCl}$ in $S$. europaea and $S$. dolichostachya. Although above this concentration increasing salinity decreased the amount and rate of germination, a proportion of seeds that had been pre-treated for 10 days at $3{ }^{\circ} \mathrm{C}$ in distilled water germinated in solutions of $\mathrm{NaCl}$ up to $1 \mathrm{M}$, about double that of sea water (Smith 1985). Increasing salinity appears to lower the optimum temperature for germination (Langlois 1966; Rivers \& Weber 1971; Huiskes et al. 1985b). Ungar (1977, 1978) found that application of $10^{-4}-10^{-3} \mathrm{M}$ gibberellic acid substantially alleviated the depression of germination associated with high salinity but kinetin had no effect. The effect of salinity on germination is a conditional dormancy, as ungerminated seeds from high salinity treatments are usually able to germinate when transferred to distilled water (e.g. Smith 1985; Garcia-Tiburcio \& Troyo-Dieguez 1993); as in other halophytes this reversibility indicates that inhibition is due to low water potential rather than ion toxicity. Keiffer \& Ungar (1997) found that subsequent germination in distilled water was stimulated by prolonged exposure to high 
700

A. J. Davy,

G. F. Bishop \&

C. S. B. Costa salinity $(3-10 \% \mathrm{NaCl})$ in North American material of S. europaea.

Populations or taxa with well-developed seed dimorphism generally have different germination requirements for the larger (central) and smaller (lateral) seeds in a cyme. This probably represents a bet-hedging strategy that has evolved in less predictable environments, with readily germinable central seeds and highly dormant lateral seeds for dispersal in time. The central seeds of dimorphic S. europaea ('S. patula') from a Mediterranean environment (Camargue) had low sensitivity to salt, needed no cold pre-treatment and were relatively indifferent to light, whereas lateral ones were highly sensitive to salinity, needed pre-treatment with cold and showed a positive response to light (Grouzis et al. 1976; Berger 1985). Similarly, the large seeds of dimorphic $S$. europaea from an inland salt marsh in Ohio, USA were more salt tolerant and yielded higher germination percentages under salinities of $0-5 \%$ than the small ones (Ungar 1979); the small seeds were more dormant and remained in a persistent seed bank, unlike the large ones which germinated in the Spring after production (Philipupillai \& Ungar 1984). Smith (1985) found no significant differences in germination behaviour between central and lateral seeds in a wide range of populations in the relatively predictable environment of a north Norfolk salt marsh, nor in initial rates of elongation of seedling radicles. Huiskes et al. (1985b) found that seeds of S. europaea ('S. brachystachya') and $S$. dolichostachya buried under a layer of sediment of $10 \mathrm{~mm}$ germinated but the seedlings failed to emerge.

Sodium chloride may be important for the establishment of seedlings. $\mathrm{NaCl}$ concentrations of $0.1-$ 0.2 m stimulated hypocotyl elongation of $S$. europaea ('S. herbacea') especially in the dark (Kawasaki et al. 1978). In S. bigelovii seedlings, the cotyledons failed to expand and growth was impaired, because water movement into plants was inhibited by lack of inorganic solutes (Stumpf et al. 1986).

\section{(E) SEEDLING MORPHOLOGY}

The seedling (Fig. 9) normally has two fleshy cotyledons and a short, thick hypocotyl. Seedlings with three cotyledons occur regularly at low frequency. The cotyledons are fused laterally towards the base to form a cotyledonary tube which is united with the hypocotyl and forms a succulent 'cortex' around it. The cotyledons have no palisade layer but aqueous tissue is well marked. The arrangement of vascular strands in the cotyledons is the same as that described for mature vegetative segments, the hypocotyl having a double series of bundles (de Fraine 1912). Transition from stem to root takes place high in the hypocotyl and is of the van Tieghem Type III (de Fraine 1912). Seedlings from one parent plant usually resemble each other closely but differ from those of other parent plants grown in similar conditions in cotyledon size and shape, presence or absence of pigmentation (betacyanin) in the hypocotyl and the number and origin of primary branches (Dalby 1955).

The lower limit of establishment of Salicornia on salt marshes often appears to be set by the time necessary for the seedlings to penetrate the sediment and develop a ring of root hairs, in order to become fully anchored. Wiehe (1935) suggested a threshold period of tidal exposure of 2-3 days for rooting sufficient to resist tidal action on the low part of an estuarine marsh. The more rapid radicle growth in $S$. dolichostachya than in $S$. europaea may give the former an establishment advantage and account for its predominance at the lowest levels of marshes (Ball \& Brown 1970).

\section{Herbivory and disease}

\section{(A) ANIMAL FEEDERS AND PARASITES}

\section{Nematoda}

Heteroderinae: Cactodera salina Baldwin, MundoOcampo \& McClure has adverse effects on oilseed crops of S. bigelovii at Sonoro, Mexico (Baldwin et al. 1997).

\section{Hemiptera}

Miridae: Orthotylus rubidus (Fieber in Puton) can have two generations on Salicornia that is not regularly submerged by the tide; the larvae are found June-August and adults July-October (Southwood \& Leston, Land and Water Bugs).

Cicadellidae: Macrosteles sordidipennis (Stål) [= M. salinus (Reuter)] has been found on Salicornia in France (Ribaut 1952) and has also been recorded in Britain, although not on Salicornia (Kloet \& Hincks 1964).

\section{Lepidoptera}

Coleophoridae: Larvae of Coleophora salicorniae Wocke typically feed on small plants of Salicornia colonizing well-drained patches in mixed vegetation. They bore into the tissues, eating the seeds, and then cut off the stem tip as a case, attaching it to another stem to continue feeding (Emmet 1979); they have been recorded generally on S. europaea agg. (Emmet 1980) and specifically on $S$. europaea, $S$. ramosissima and S. fragilis (Heal 1982, 1983). Females of Coleophora atriplicis Meyrick oviposit in July on the flowers of Atriplex portulacoides. The larvae build silk-lined cases and feed successively on pollen, developing embryos and seeds until diapause in October or November. In autumn, they also migrate to adjacent $S$. ramosissima plants, where they bore into the seeds and can have considerable impact on reproductive output (Proudfoot 1993). In Rhode Island (USA) salt marshes, the spring generation larvae of the bivoltine Coleophora caespititiella Zeller feed on Juncus gerardii, whilst the autumnal generation feeds on $S$. europaea, consuming up to $25 \%$
Ecological Society, Journal of Ecology, 89, 681-707 
Salicornia L.

of the seeds (Ellison 1991). This species has been recorded in Britain but apparently not on Salicornia (Emmet 1979).

Gelechiidae: Eggs of Scrobipalpa salinella (Zeller) have been found on Salicornia in Britain (Emmet 1979) and the larvae feed on $S$. europaea in central Europe (Povolny 1980). Povolny also recorded larvae of Scrobipalpa instabilella (Douglas) and S. nitentella (Fuchs) on Salicornia europaea, and those of S. obsoletella (Fischer von Roslerstamm) on Salicornia spp.

\section{Coleoptera}

Chrysomelidae: Cassida nobilis L. and C. vittata de Vill. feed on Salicornia spp. (Walsh \& Dibb 1954). Erynephala maritima Lac. is a significant herbivore of S. europaea on New England salt marshes (Ellison 1987a; Rand 1999). Larvae of Metachroma sp. have been reported to kill Salicornia seedlings in the USA (Stanghellini et al. 1988).

Curculionidae: Baris scolopacea Germar is found on Salicornia (Walsh \& Dibb 1954); Hoffmann (1954) specified the presence of adults on S. europaea.

\section{Diptera}

Cecidomyiidae: Larvae of the gall midge Baldratia salicorniae Kieffer inhabit the internodes of S. europaea (Buhr, Gallen). Baldratia jaxarctica Fedotova has recently been described from $S$. europaea in Kazakhstan (Fedotova 1992).

Ephydridae: Clanoneurum cimiciforme (Haliday) larvae feed on Salicornia (Uffen \& Chandler 1978).

\section{Acarina}

Eriophyiidae: Eriophyes salicorniae Nalepa larvae and adults cause witches' brooms on $S$. europaea (Davis et al. 1982).

\section{Aves}

Twite (Carduelis flavirostris), linnets (C. cannabina) and shore-larks (Eremophila alpestris) feed on readily disarticulating spikes of Salicornia (Petch \& Swann 1968). Mallard (Ananas platyrhynchos), pintail (A. acuta), teal (A. crecca), wigeon (A. penelope), shoveller (Spatula clypea), redshank (Tringa totanus), chaffinch (Fringilla coelebs) and thrush (Turdus sp.) are all known to feed on the seeds (Hilton 1975). Brown \& Atkinson (1996) record that Suaeda/Salicornia salt marshes are amongst the communities most used by wintering coastal passerines, particularly twite and skylark (Alauda arvensis). Mature plants of S. europaea agg. containing seeds form much of the diet of dark-

(C) 2001 British Ecological Society, Journal of Ecology, 89, 681-707 bellied brent geese (Branta bernicla bernicla) on the north Norfolk coast in autumn (Summers et al. 1993). Rowcliffe et al. (1998) reported a strong aggregative response to this preferred food. Salicornia europaea on
New England salt marshes is relatively unpalatable to Canada geese (Branta canadensis), whilst S. bigelovii has a positive chemical defence mechanism, including a pungent odour, against being eaten by this species (Buchsbaum et al. 1984); in S. europaea there is an increase in the percentage of phenolic substances, thought to render the plants unpalatable to Canada geese, from May to September (Buchsbaum \& Valiela 1987).

\section{Mammalia}

Testas of Salicornia seeds have been reported in the faecal pellets of rabbits (Oryctolagus cuniculus) on a salt marsh; yellow-necked fieldmice (Apodemus flavicollis) sought out and consumed stored seed in preference to potatoes, carrots and apples (Hilton 1975).

\section{Domestic animals and Man}

Salicornia bigelovii has been grown as an oil-seed and forage crop in arid environments, as it may be irrigated with seawater or other saline waters. It can yield 10-20 $\mathrm{t} \mathrm{ha} \mathrm{a}^{-1}$ of seed, containing $28 \%$ oil and $31 \%$ protein with only $5-7 \%$ fibre and ash (Glenn et al. 1991, 1999). It is acceptable as the forage component of diets fed to goats (Glenn et al. 1992) and a by-product of oil extraction, Salicornia meal, may be used as an ingredient in broiler chicken diets (Attia et al. 1997).

Salicornia has a long history of human consumption as a vegetable and in pickles (Chevalier 1922). In Britain it has long been collected as samphire for eating.

\section{(B) PLANT PARASITES}

Booth et al. (1988) provide a review of fungal records, world-wide, on Salicornia europaea agg. and a detailed analysis of fungal assemblages on populations in sulphate-dominated, alkaline lakes in Manitoba and Saskatchewan, Canada. Sixty-five species of fungi have been reported from its rhizosphere and 80 taxa from the root and stem surfaces, seeds, moribund plants and dead material. Except where otherwise attributed, the following summary is from this source. Rhizosphere fungi are not included.

\section{Zygomycotina}

Mucorales: Mortierella (1 sp.), Mucor (1 sp.).

\section{Ascomycotina}

Chaetomium (1 sp.), Didymosphaeria (1 sp.), Hypoxylon (1 sp.), Leptosphaeria (1 sp.), Mycosphaerella (1 sp.), Pleospora (8 spp.), Protomyces (1 sp.).

\section{Basidiomycotina}

In Britain, the rust Uromyces salicorniae de Bary is found uncommonly on leaves and stems of S. europaea 
702

A. J. Davy,

G. F. Bishop \&

C. S. B. Costa

and $S$. ramosissima; aecia are mostly on young plants in May (Ellis \& Ellis 1985).

\section{Deuteromycotina}

Stagnosporopsis salicorniae (P. Magnus) Died. occurs on lower part of stems of S. europaea in July; scattered pycnidia are visible (Ellis \& Ellis 1985). Records from Booth et al. (1988): Acremonium (7 spp.), Alternaria (9 spp.), Arthrinium (1 sp.), Ascochyta (2 spp.), Aspergillus (1 sp.), Aureobasidium (1 sp.), Botrytis (1 sp.), Camarosporium (3 spp.), Cladosporium (4 spp.), Coniella (1 sp.), Coniothyrium (1 sp.), Dendryphiella (2 spp.), Diplodina (1 sp.), Doratomyces (1 sp.), Drechslera (2 spp.), Epicoccum (1 sp.), Fusarium (4 spp.), Gliocladium (1 sp.), Gliomastix (1 sp.), Monodictys (1 sp.), Papulaspora (1 sp.), Penicillium spp., Phoma (2 spp.), Phomopsis (1 sp.), Scopulariopsis (1 sp.), Scytalidium (1 sp.), Septoria (1 sp.), Stagonospora (1 sp.), Stemphylium (3 spp.), Trichocladium (1 sp.), Trichoderma (2 spp.), Tubercularia (1 sp.).

An indigenous, Mexican, soil-borne fungus, Macrophomina phaseolina, infects roots and causes mortality in S. bigelovii (Stanghellini et al. 1992).

\section{(C) PLANT DISEASES}

See (B) above.

\section{History}

Salicornia is recorded from Flandrian deposits of the East Anglian Fenland. At Littleport, where it is accompanied by Suaeda maritima, it is in deposits close to the margin of the Fen Clay that were laid down in a marine transgression culminating about 2000 BC. At Saddlebow it has been found in deposits from the subsequent marine transgression in Roman times (Godw. Hist.).

The vernacular name 'samphire' is derived from 'sampere', an early English name from the French 'herbe de St. Pierre' (Wilson 1980). The common name 'glasswort' arose from the use of its soda-rich ashes in early glass making. William Turner's Herball (part iii) refers to it as 'saltwurt' and 'glaswede' in 1568; the name Salicornia originates from the 'Pemptades' of Dodonaeus in 1583 (First Rec.). Linnaeus described the genus Salicornia (Species Plantarum edn 2, 1763) to include all succulent and apparently leafless chenopodiaceous plants. Scott (1977) has provided an historical survey of subsequent taxonomic revisions resulting in its restriction to annual species. Pioneering taxonomic work on Salicornia was undertaken by Woods (1851), Dumortier (1868), Duval-Jouve (1868) and Moss (1911, 1912).

(C) 2001 British Ecological Society, Journal of Ecology, 89, 681-707

\section{Conservation}

British and other European habitats supporting low marsh and mud-flat stands of Salicornia have been given legal status and protection as 'Special Areas of Conservation' under a Habitats Directive of the European Union.

\section{Acknowledgements}

We thank Mrs J. M. Croft and Dr C. D. Preston for preparing the British distribution maps and Dr L. K. Ward for information from the ITE (now, Centre for Ecology and Hydrology) Phytophagous Insects Data Bank. Dr I. Teräs, the Committee for Mapping the Flora of Europe and Societas Biologica Fennica Vanamo kindly allowed reproduction of the European distribution maps. We are grateful to James Goodwin for the excellent drawings of seedlings (Fig. 9). Paul Adam, Bob Jefferies, Michael Proctor and Arthur Willis all provided valuable comments and information.

\section{References}

Adam, P. (1978) Geographical variation in British saltmarsh vegetation. Journal of Ecology, 66, 339-366.

Adam, P. (1981) The vegetation of British saltmarshes. New Phytologist, 88, 143-196.

Albert, R. (1975) Salt regulation in halophytes. Oecologia, 21, $57-71$.

Al-Turki, T.A. (1992) Systematic and Ecological studies of Suaeda and Salicornia from Saudi Arabia and Britain. $\mathrm{PhD}$ Thesis, University of East Anglia, Norwich, UK.

Al-Turki, T.A. (1997) A preliminary checklist of the flora of Qassim, Saudi Arabia. Feddes Repertorium, 108, 259280.

Arakawa, Y., Asada, Y., Ishida, H., Chiji, H. \& Izawa, M. (1982) Structures of new two isoflavones and one flavonone from glasswort (Salicornia europaea L.). Journal of the Faculty of Agriculture, Hokkaido University, 61, 1-12.

Arakawa, Y., Chiji, H. \& Izawa, M. (1983) Structural elucidation of 2 new chromones isolated from glasswort (Salicornia europaea L.). Agricultural and Biological Chemistry, 47, 2029-2033.

Attia, F.M., Al-Sobayel, A.A., Kriadees, M.S., Al-Saiady, M.Y. \& Bayoumi, M.S. (1997) Nutrient composition and feeding value of Salicornia bigelovii Torr. meal in broiler diets. Animal Feed Science and Technology, 65, 257-263.

Austenfeld, F.-A. (1986) Nutrient reserves of Salicornia europaea seeds. Physiologia Plantarum, 68, 446-450.

Austenfeld, F.-A. (1988) Seed dimorphism in Salicornia: nutrient reserves. Physiologia Plantarum, 73, 502-504.

Ayala, F. \& O'Leary, J.W. (1995) Growth and physiology of Salicornia bigelovii Torr. at suboptimal salinity. International Journal of Plant Sciences, 156, 197-205.

Ayala, F., O'Leary, J.W. \& Schumaker, K.S. (1996) Increased vacuolar and plasma-membrane $\mathrm{H}^{+}$-ATPase activities in Salicornia bigelovii Torr. in response to $\mathrm{NaCl}$. Journal of Experimental Botany, 47, 25-32.

Baker, J.M. (1979) Responses of salt marsh vegetation to oil spills and refinery effluents. Ecological Processes in Coastal Environments (eds R.L. Jefferies \& A.J. Davy), pp. 529-542. Blackwell Scientific Publications, Oxford, UK.

Baldwin, J.G., Mundo-Ocampo, M. \& McClure, M.A. (1997) Cactodera salina $\mathrm{n}$. sp. from the estuary plant, Salicornia bigelovii, in Sonoro, Mexico. Journal of Nematology, 29, 465-473.

Ball, P.W. (1964) A taxonomic review of Salicornia in Europe. Feddes Repertorium, 69, 1-8. 
Ball, P.W. \& Brown, K.G. (1970) A biosystematic and ecological study of Salicornia in the Dee estuary. Watsonia, $\mathbf{8}$, $27-40$.

Ball, P.W. \& Tutin, T.G. (1959) Notes on annual species of Salicornia in Britain. Watsonia, 4, 193-205.

Beeftink, W.G. (1985) Population dynamics of annual Salicornia species in the tidal salt marshes of the Oosterschelde, the Netherlands. Vegetatio, 61, 127-136.

Benito, I. \& Onaindia, M. (1991) Biomass and aboveground production of four angiosperms in Cantabrian (north Spain) salt marshes. Vegetatio, 96, 165-175.

Berger, A. (1985) Seed dimorphism and germination behaviour in Salicornia patula. Vegetatio, 61, 137-143.

Bernatksy, J. (1905) Über die Halophytenvegetation des Sodaboden im Ungarischen Tieflande. Annales Musei Nationalis Hungarici, 3, 125-214.

Bertness, M.D., Gough, L. \& Shumway, S.W. (1992) Salt tolerances and the distribution of fugitive salt marsh plants. Ecology, 73, 1842-1851.

Binet, P. \& Langlois, J. (1962) Précisions sur quelque caractères de Salicornia stricta Dumort., Salicornia patula Moss et Salicornia apressa Dumort. Bulletin de la Société Botanique de France, 108, 387-393.

Booth, T., Gorrie, S. \& Muhsin, T.M. (1988) Life strategies among fungal assemblages on Salicornia europaea aggregate. Mycologia, 80, 176-191.

Borkowski, B. \& Drost, K. (1965) Alkaloide aus Salicornia herbacea L. Pharmazie, 20, 390-393.

Brereton, A.J. (1971) The structure of the species populations in the initial stages of salt-marsh succession. Journal of Ecology, 59, 321-338.

Brewer, J.S., Levine, J.M. \& Bertness, M.D. (1998) Interactive effects of elevation and burial with wrack on plant community structure in some Rhode Island salt marshes. Journal of Ecology, 86, 125-136.

Briens, M. \& Larher, F. (1982) Osmoregulation in halophytic higher plants: a comparative study of soluble carbohydrates, polyols, betaines and free proline. Plant, Cell and Environment, 5, 287-292.

Brown, A.F. \& Atkinson, P.W. (1996) Habitat associations of coastal wintering passerines. Bird Study, 43, 188-200.

Buchsbaum, R. \& Valiela, I. (1987) Variability in the chemistry of estuarine plants and its effect on feeding by Canada geese. Oecologia, 73, 146-153.

Buchsbaum, R., Valiela, I. \& Swain, T. (1984) The role of phenolic compounds and other plant constituents in feeding by Canada geese in a coastal marsh. Oecologia, 63, 343-349.

Carey, A.E. \& Oliver, F.W. (1918) Tidal Lands: a Study of Shore Problems. Blackie \& Son, London, UK

Carolin, R.C., Jacobs, S.W. \& Vesk, M. (1982) The chlorenchyma of some members of the Salicornieae (Chenopodiaceae). Australian Journal of Botany, 30, 387-392.

Castroviejo, S. \& Coello, P. (1980) Datos cariologicos y taxonomicos sobre las Salicorniinae A.J. Scott Ibericas. Anales del Jardin Botanico de Madrid, 37, 41-73.

Chapman, V.J. (1960) The plant ecology of Scolt Head Island. Scolt Head Island, 2nd edn (ed. J.A. Steers), pp. 85-163. Heffer, Cambridge, UK.

Chevalier, A. (1922) Les Salicornes et leur emploi dans l'alimentation: Etude historique, botanique, économique. Revue de Botanique appliquée et d'Agriculture coloniale, 2, 697-785.

Chiji, H. (1976) Studies on betalain pigments of Centrospermae plants with special reference to a violet red pigment in Salicornia europaea L. Memoirs of the Faculty of Agriculture, Hokkaido University, 9, 303-372.

(C) 2001 British Ecological Society, Journal of Ecology, 89, 681-707

Chiji, H., Aiba, T. \& Izawa, M. (1978) Isolation and identification of two 2,3-unsubstituted chromones from glasswort (Salicornia europaea L.). Agricultural and Biological Chem-
Contandriopoulos, J. (1968) A propos des nombres chromosomiques des Salicornia de la région méditerranéenne. Bulletin du Musé d' Histoire Naturelle de Marseille, 28, 4552.

Cooper, A. (1982) The effects of salinity and waterlogging on the growth and cation uptake of salt marsh plants. New Phytologist, 90, 263-275.

Cooper, A. (1984) A comparative study of the tolerance of salt marsh plants to manganese. Plant and Soil, 81, 47-59.

Costa, C.S.B. (1992) Competition and coexistence in the salt marsh annuals Suaeda maritima and Salicornia europaea. $\mathrm{PhD}$ Thesis, University of East Anglia, Norwich, UK.

Costa, C.S.B. \& Davy, A.J. (1992) Coastal salt marshes of Latin America. Coastal Plant Communities of Latin America (ed. U. Seeliger), pp. 179-199. Academic Press Inc., San Diego, California, USA.

Cristofolini, G. (1968) A serotaxonomic approach to the complex 'Salicornia herbacea' L. Giornale Botanico Italiano, 102, 555-556.

Cristofolini, G. \& Chiapella, L. (1970) Chemotassonomia del genere Salicornia delle coste venete. Giornale Botanico Italiano, 104, 91-115.

Dalby, D.H. (1955) Some variation in Salicornia and its significance. Species Studies in the British Flora (ed. J.E. Lousley), pp. 133-134. BSBI, Buncle, Arbroath, UK.

Dalby, D.H. (1962) Chromosome number, morphology and breeding behaviour in the British Salicorniae. Watsonia, 5, $150-162$.

Dalby, D.H. (1963) Seed dispersal in Salicornia pusilla. Nature, 199, 197-198.

Dalby, D.H. (1989) An expert's approach to the Salicornia problem. Botanical Society of the British Isles News, 53, 9-10.

Davis, R., Fletchman, C.H.W., Boczek, J.H. \& Barke, H.E. (1982) Catalogue of Eriophyid Mites. Warsaw Agricultural University Press, Warsaw, Poland.

Davy, A.J., Costa, C.S.B., Yallop, A.R., Proudfoot, A.M. \& Mohamed, M.F. (2000) Biotic interactions in plant communities of saltmarshes. British Saltmarshes (eds B.R. Sherwood, B.G. Gardiner \& T. Harris), pp. 109-127. Linnean Society/Forrest Text, Ceredigion, UK

Davy, A.J., Noble, S.M. \& Oliver, R.P. (1990) Genetic variation and adaptation to flooding in plants. Aquatic Botany, 38, 91-108.

Davy, A.J. \& Smith, H. (1985) Population differentiation in the life-history characteristics of salt marsh annuals. Vegetatio, 61, 117-125.

Davy, A.J. \& Smith, H. (1988) Life-history variation and environment. Plant Population Ecology (eds A.J. Davy, M.J. Hutchings \& A.R. Watkinson), pp. 1-22. Blackwell Scientific Publications, Oxford, UK.

van Diggelen, J., Rozema, J. \& Broekman, R. (1987) Growth and mineral relations of salt-marsh species on nutrient solutions containing various sodium sulphide concentrations. Vegetation Between Land and Sea (eds A.H.L. Huiskes, C.W.P.M. Blom \& J. Rozema), pp. 260-268. Dr W. Junk, Dordrecht, the Netherlands.

Dumortier, B.C. (1868) Bouqet du littoral Belge. Bulletin de la Société Botanique de Belge, 7, 332-334.

Duval-Jouve, M.J. (1868) Des Salicornia de l'Hérault. Bulletin de la Société Botanique de France, 15, 165-178.

Ellenberg, H. (1988) Vegetation Ecology of Central Europe. Cambridge University Press, Cambridge, UK.

Ellis, M.B. \& Ellis, J.P. (1985) Microfungi on Land Plants: an Identification Handbook. Croom-Helm, London, UK.

Ellison, A.M. (1987a) Effects of competition, disturbance, and herbivory on Salicornia europaea. Ecology, 68, 576-586.

Ellison, A.M. (1987b) Density-dependent dynamics of Salicornia europaea monocultures. Ecology, 68, 737-741. istry, 42, 159-165.
Ellison, A.M. (1989) Morphological determinants of selfthinning in plant monocultures and a proposal concerning the role of self-thinning in plant evolution. Oikos, 54, 287-293. 
704

A. J. Davy,

G. F. Bishop \&

C. S. B. Costa
Ellison, A.M. (1991) Ecology of case-bearing moths (Lepidoptera, Coleophoridae) in a New England salt marsh. Environmental Entomology, 20, 857-864.

Ellison, A.M. \& Niklas, K.J. (1988) Branching patterns of Salicornia europaea (Chenopodiaceae) at different successional stages: a comparison of theoretical and real plants. American Journal of Botany, 75, 501-512.

Ellison, A.M., Niklas, K.J. \& Shumway, S. (1993) Xylem vascular anatomy and water transport of Salicornia europaea. Aquatic Botany, 45, 325-339.

El-Mallah, M.H., Murui, T. \& El-Shami, S. (1994) Detailed studies on seed oil of Salicornia SOS-7 cultivated at the Egyptian border of Red-Sea. Grasas y Aceites, 45, 385-389.

El-Shami, S.M. \& El-Negoumy, S.I. (1993) Tocopherols and flavonoids of SOS-7 halophyte. Grasas y Aceites, 44, 249 252.

Emmet, A.M. (1979) A Field Guide to the Smaller British Lepidoptera. The British Entomological and Natural History Society, London, UK.

Emmet, A.M. (1980) Report on exhibits shown on 11 October, 1979. Proceedings and Transactions of the British Entomological and Natural History Society, 13, 59-60.

Fahn, A. (1974) Plant Anatomy. Pergamon Press, Oxford, UK. Fahn, A.F. \& Arzee, T. (1959) Vascularization of articulated Chenopodiaceae and the nature of their fleshy cortex. American Journal of Botany, 46, 330-338.

Fedotova, Z.A. (1992) Gall midges of the subtribe Baldratiina (Diptera, Cecidomyiidae, Lasiopterini) in Kazakhstan. Zoologichesky Zhurnal, 71, 42-51.

Ferguson, I.K. (1964a) A study of the taxonomy of Salicornia L. in Ireland. PhD Thesis, University of Dublin, Ireland.

Ferguson, I.K. (1964b) Notes on the stigma morphology and flowering behaviour of British Salicorniae. Watsonia, 6, 25-27. Journal of the Linnean Society, Botany, 41, 317-348.

Garcia-Tiburcio, H. \& Troyo-Dieguez, E. (1993) Effects of sudden drop in salinity on germination of Salicornia bigelowii Torr. in the laboratory. Phyton-International Journal of Experimental Botany, 54, 127-137.

Gerdol, V. \& Hughes, R.G. (1993) Effect of the amphipod Corophium volutator on the colonization of mud by the halophyte Salicornia europaea. Marine Ecology-Progress Series, 97, 61-69.

Geslin, M. \& Verbist, J.F. (1985) Flavonoids from Salicornia europaea. Journal of Natural Products - Lloydia, 48, 111113.

Glenn, E.P., Brown, J.J. \& Blumwald, E. (1999) Salt tolerance and crop potential of halophytes. Critical Reviews in Plant Science, 18, 227-255.

Glenn, E.P., Coates, W.E., Riley, J.J., Kuehl, R.O. \& Swingle, R.S. (1992) Salicornia bigelovii Torr. - a seawater-irrigated forage for goats. Animal Feed Science and Technology, 40, 21-30.

Glenn, E., O’Leary, J.W., Watson, C.M., Thompson, T.L. \& Kuehl, R.O. (1991) Salicornia bigelovii Torr. an oilseed halophyte for seawater irrigation. Science, 251, 1065-1067.

Gorham, J., Hughes, L. \& Wyn Jones, R.G. (1980) Chemical composition of salt-marsh plants from Ynys Mon (Anglesey): the concept of physiotypes. Plant, Cell and Environment, $\mathbf{3}$, 309-318.

Grouzis, M. (1973) Exigences écologiques comparées d'une salicorne vivace et d'une salicorne annuelle: germination et croissance des stades jeunes. Oecologia Plantarum, 8, 367375.

Grouzis, M., Berger, A. \& Heim, G. (1976) Polymorphisme et germination des graines chez trois espèces annuelles du genre Salicornia. Oecologia Plantarum, 11, 41-52.

Ecological Society, Journal of Ecology, 89, 681-707 accumulation de sels chez deux salicornes annuelles du de Fraine, E. (1912) The anatomy of the genus Salicornia.

Guy, R.D., Reid, D.M. \& Krouse, H.R. (1986) Factors affecting ${ }^{13} \mathrm{C} /{ }^{12} \mathrm{C}$ ratios of inland halophytes. II. Ecophysiological interpretations of patterns in the field. Canadian Journal of Botany, 64, 2700-2707.

Hacker, S.D. \& Bertness, M.D. (1999) Experimental evidence for factors maintaining plant species diversity in a New England salt marsh. Ecology, 80, 2064-2073.

Hagène, P. (1958) Sur des variations de la teneur en acide ascorbique dans des espèces du genre Salicornia. Comptes Rendus des Séances de l'Académie des Sciences, 246, 809-812.

Halket, A.C. (1915) The effect of salt on the growth of Salicornia. Annals of Botany, 29, 143-155.

Halket, A.C. (1928) The morphology of Salicornia - an abnormal plant. Annals of Botany, 42, 525-530.

Hambler, D.J. (1954) Chromosome numbers in British Salicornia. Nature, 173, 547.

Harley, C.D.G. \& Bertness, M.D. (1996) Structural interdependence: An ecological consequence of morphological responses to crowding in marsh plants. Functional Ecology, 10, 654-661.

Havill, D.C., Ingold, A. \& Pearson, J. (1985) Sulphide tolerance in coastal halophytes. Vegetatio, 62, 279-285.

Heal, N.F. (1982) Foodplant of Coleophora salicorniae Wocke identified as Salicornia fragilis P.W. Ball and Tutin. Entomologist's Record and Journal of Variation, 94, 103.

Heal, N.F. (1983) Further notes upon the foodplant of Coleophora salicorniae Wocke. Entomologist's Record and Journal of Variation, 95, 64.

von Hedenström, H. \& Breckle, S.W. (1974) Obligate halophytes? A test with tissue culture techniques. Zeitschrift zur Pflanzenphysiologie, 74, 183-185.

Hildebrandt, U., Janetta, K., Ouziad, F., Renne, B., Nawrath, K. \& Bothe, H. (2001) Arbuscular mycorrhizal colonization of halophytes in Central European salt marshes. Mycorrhiza, 10, $175-183$.

Hilton, J.R. (1975) Studies on the biology of Salicornia dolichostachya Moss. PhD Thesis, University of Exeter, UK.

Hoffmann, A. (1954) Faune de France, Vol. 59. Coleoptères Curculionides. Lechevalier, Paris, France.

Huiskes, A.H.L., Schat, H. \& Elenbaas, P.F.M. (1985a) Cytotaxonomic status and morphological characterisation of Salicornia dolichostachya and Salicornia brachystachya. Acta Botanica Neerlandica, 34, 271-282.

Huiskes, A.H.L., Stienstra, A.W., Koutstaal, B.P., Markusse, M.M. \& van Soelen, J. (1985b) Germination ecology of Salicornia dolichostachya and Salicornia brachystachya. Acta Botanica Neerlandica, 34, 369-380.

Hultén, E. (1970) The Circumpolar Plants. II Dicotyledons. Almqvist \& Wiksell, Stockholm, Sweden.

Ingold, A. \& Havill, D.C. (1984) The influence of sulphide on the distribution of higher plants in salt marshes. Journal of Ecology, 72, 1043-1054.

Ingrouille, M. (1989) A non-expert's approach to the Salicornia problem. Botanical Society of the British Isles News, 53, 1112.

Ingrouille, M.J. \& Pearson, J. (1987) The pattern of morphological variation in the Salicornia europaea L. aggregate (Chenopodiaceae). Watsonia, 16, 269-281.

Ingrouille, M.J., Pearson, J. \& Havill, D.C. (1990) The pattern of morphological variation in the Salicornia dolichostachya Moss group from different sites in southern England. Acta Botanica Neerlandica, 39, 263-273.

James, L.E. \& Kyhos, D.W. (1961) The nature of the fleshy shoot of Allenrolfea and allied genera. American Journal of Botany, 48, 101-108.

Jefferies, R.L. (1972) Aspects of salt-marsh ecology with particular reference to inorganic plant nutrition. The Estuarine Environment (eds R.S.K. Barnes \& J. Green), pp. 61-85. Applied Science Publishers, Barking, UK.

Grouzis, M., Heim, G. \& Berger, A. (1977) Croissance et littoral méditerranéen. Oecologia Plantarum, 12, 307-322.
Jefferies, R.L. (1977) Growth responses of coastal halophytes to inorganic nitrogen. Journal of Ecology, 65, 847-865. 
Salicornia L.
Jefferies, R.L., Davy, A.J. \& Rudmik, T. (1979) The growth strategies of coastal halophytes. Ecological Processes in Coastal Environments (eds R.L. Jefferies \& A.J. Davy),

Jefferies, R.L., Davy, A.J. \& Rudmik, T. (1981) Population biology of the salt marsh annual Salicornia europaea agg. Journal of Ecology, 69, 17-31.

Jefferies, R.L. \& Gottlieb, L.D. (1982) Genetic differentiation of the microspecies Salicornia europaea L. (sensu stricto) and S. ramosissima J. Woods. New Phytologist, 92, 123-129.

Jefferies, R.L., Jensen, A. \& Bazely, D. (1983) The biology of the annual Salicornia europaea agg. at the limits of its range in Hudson Bay. Canadian Journal of Botany, 61, 762-773.

Jefferies, R.L. \& Perkins, N. (1977) The effects on the vegetation of the additions of inorganic nutrients to salt marsh soils at Stiffkey, Norfolk. Journal of Ecology, 65, 867-882.

Jensen, A. \& Jefferies, R.L. (1984) Fecundity and mortality in populations of Salicornia europaea agg. at Skallingen, Denmark. Holarctic Ecology, 7, 399-412.

Joenje, W. (1978) Plant colonization and succession on embanked sand flats; a case study in the Lauwerszeepolder. PhD Thesis. University of Groningen, the Netherlands.

Kawasaki, H., Takada, H. \& Kamisaka, S. (1978) Requirement of sodium chloride for the action of gibberellic acid in stimulating hypocotyl elongation of a halophyte, Salicornia herbacea L. Plant and Cell Physiology, 19, 1415-1425.

Keiffer, C.H., McCarthy, B.C. \& Ungar, I.A. (1994) Effect of salinity and waterlogging on growth and survival of Salicornia europaea L., an inland halophyte. Ohio Journal of Science, 94, 70-73.

Keiffer, C.H. \& Ungar, I.A. (1997) The effect of extended exposure to hypersaline conditions on the germination of five inland halophyte species. American Journal of Botany, 84, 104-111.

Kiehl, K., Eischeid, I., Gettner, S. \& Walter, J. (1996) Impact of different sheep grazing intensities on salt-marsh vegetation in Northern Germany. Journal of Vegetation Science, 7, 99-106.

Klecka, A. \& Vukolov, V. (1937) Comparative studies of the mycorrhiza of meadow halophytes [abstract]. Review of Applied Mycology, 16, 768.

Kloet, G.S. \& Hincks, W.D. (1964) A Check List of British Insects. Part 1: Small Orders and Hemiptera, 2nd edn. Royal Entomological Society of London, London, UK.

Knoerr, A. (1968) Nouvelles observations sur les Salicornes cultures expérimentales, mesures de graines. Bulletin $d u$ Museum d'Histoire Naturelle de Marseille, 28, 189-203.

König, D. (1939) Die Kromosomerverhaltnisse der deutschen Salicornia. Planta, 29, 361-375.

König, D. (1960) Beiträge zur Kenntnis der deutschen Salicornien. Mitteilungen der Floristisch-Soziologischen Arbeitsgemeinschaft, 8, 5-58.

Koutstaal, B.P., Markusse, M.M. \& de Munck, W. (1987) Aspects of seed dispersal by tidal movements. Vegetation Between Land and Sea (eds A.H.L. Huiskes, C.W.P.M. Blom \& J. Rozema), pp. 226-233. Dr W. Junk, Dordrecht, the Netherlands.

Kuramoto, R.T. \& Brest, D.E. (1979) Physiological response to salinity by four salt marsh plants. Botanical Gazette, $\mathbf{1 4 0}$, 295-298.

Kurkova, E.B. \& Balnokin, Y.V. (1994) Pinocytosis and its possible role in ion-transport in the salt-accumulating organs of halophytes. Russian Journal of Plant Physiology, 41, 507-511.

Langlois, J. (1961a) Croissance, morphogenèse et floraison de trois variétés de Salicornia herbacea. Bulletin de la Société Linnéenne de Normandie, 10, 261-276.

(C) 2001 British Ecological Society, Journal of Ecology, 89, 681-707

Langlois, J. (1961b) Aspects morphologiques et écophysiologiques de la germination de trois variétés de Salicornia herbacea L. Bulletin de la Société Linnéenne de Normandie, pp. 243-268. Blackwell Scientific Publications, Oxford, UK.

Langlois, J. (1966) Etude comparée de l'aptitude à germer des graines de Salicornia stricta Dumort., S. disarticulata Moss and $S$. radicans Smith. Revue Générale de Botanique, 73, $25-39$.

Langlois, J. (1967) Cultures sans sol de Salicornia stricta Dumort. Revue Générale de Botanique, 74, 176-196.

Langlois, J. (1968a) Evolution de la pression osmotique et des teneurs en eau, en $\mathrm{Cl}^{-}$et $\mathrm{Na}^{+}$au cours de la croissance de l'axe principal chez Salicornia stricta Dumort. Revue Générale de Botanique, 75, 377-394.

Langlois, J. (1968b) Néoténie chez Salicornia stricta Dumort. Bulletin de la Société Botanique de France, 115, 353-358.

Langlois, J. (1969) Action du rythme d'immersion sur la protéogenèse chez Salicornia stricta Dumort. Comptes Rendus des Séances de l'Académie des Sciences, Paris, Série D, 269, 2351-2354.

Langlois, J. (1971a) Influence du rythme d'immersion sur la croissance et le métabolisme protéique de Salicornia stricta Dumort. Oecologia Plantarum, 6, 227-245.

Langlois, J. (1971b) Influence de l'immersion sur le métabolisme glucidique de Salicornia stricta Dumort. Oecologia Plantarum, 6, 15-24.

Langlois, J. \& Ungar, I.A. (1976) A comparison of the effect of artificial tidal action on the growth and protein nitrogen content of Salicornia stricta Dumort. \& Salicornia ramosissima Woods. Aquatic Botany, 2, 43-50.

Lee, J.A. (1977) The vegetation of British inland salt marshes. Journal of Ecology, 65, 673-698.

Lee, C.W., Glenn, E.P. \& O'Leary, J.W. (1992) In vitro propagation of Salicornia bigelovii by shoot-tip cultures. Hortscience, 27, 472.

Lötschert, W. (1970) Keimung, Transpiration, Wasser- und Ionenaufnahme bei Glycophyten und Halophyten. Oecologia Plantarum, 5, 287-300.

Ludwig, W. (1950) Der Queller (Salicornia europaea) in der Wetterau. Natur und Volk, 80, 176.

Luque, C.J., Castellanos, E.M., Castillo, J.M., Gonzales, M., Gonzales-Vilches, M.C. \& Figuero, M.E. (1999) Metals in halophytes of a contaminated estuary (Odiel Saltmarshes, SW Spain). Marine Pollution Bulletin, 38, 49-51.

Luque, T., Ruiz, C., Avalos, J., Calderon, I.L. \& Figueroa, M.E. (1995) Detection and analysis of genetic variation in Salicornieae (Chenopodiaceae) using random amplified polymorphic (RAPD) markers. Taxon, 44, 53-63.

McGraw, D.C. \& Ungar, I.A. (1981) Growth and survival of the halophyte Salicornia europaea L. under saline field conditions. Ohio Journal of Science, 81, 100-113.

Momonoki, Y.S. \& Kamimura, H. (1994) Studies on the mechanism of salt tolerance in Salicornia europaea L. 1. Changes in $\mathrm{pH}$ and osmotic-pressure in Salicornia plants during the growth period. Japanese Journal of Crop Science, 63, 518-523.

Momonoki, Y.S., Kato, S. \& Kamimura, H. (1994) Studies on the mechanism of salt tolerance in Salicornia europaea L. 2. High osmosis of epidermal-cells in stem. Japanese Journal of Crop Science, 63, 650-656.

Momonoki, Y.S., Oguri, S., Kato, S. \& Kamimura, H. (1996) Studies in the mechanism of salt tolerance in Salicornia europaea L. Japanese Journal of Crop Science, 65, 693699.

Moss, C.E. (1911) Some species of Salicornia. Journal of Botany, 49, 177-185.

Moss, C.E. (1912) The genus Salicornia in Denmark. Journal of Botany, 50, 94-95.

Mucina, L., Grabner, G. \& Ellmauer, T. (1993) Die Pflanzengesellschaften Österreichs. Gustav Fischer, Jena, Germany.

Nannfeldt, J.A. (1955) Nagot om slaktet Salicornia i Sverige. Svensk Botanisker Tidskrift, 49, 97-109. 10, 160-174.
Noble, S.M. (1990) Molecular variation between populations of annual halophytes. PhD Thesis, University of East Anglia, Norwich, UK. 
A. J. Davy,

G. F. Bishop \&

C. S. B. Costa

Noble, S.M., Davy, A.J. \& Oliver, R.M. (1992) Ribosomal DNA variation and population differentiation in Salicornia L. New Phytologist, 122, 553-565.

O'Callaghan, M. (1992) The ecology and identification of the southern African Salicornieae (Chenopodiaceae). South African Journal of Botany, 58, 430-439.

Parriaud, H. (1971) Contribution à l'étude cyto-taxonomique des salicornes herbacées du sud-ouest de la France. Vie et Milieu, 22 (Suppl.), 243-251.

Pearson, J. \& Havill, D.C. (1988) The effect of hypoxia and sulphide on culture-grown wetland and non-wetland plants. II. Metabolic and physiological changes. Journal of Experimental Botany, 39, 431-439.

Petch, C.P. \& Swann, E.L. (1968) Flora of Norfolk. Jarrold, Norwich, UK.

Philipupillai, J. \& Ungar, I.A. (1984) The effect of seed dimorphism on the germination and survival of Salicornia europaea L. populations. American Journal of Botany, 71, 542-549.

Pigott, C.D. (1969) Influence of mineral nutrition on the zonation of flowering plants in coastal salt marshes. Ecological Aspects of the Mineral Nutrition of Plants (ed. I. Rorison), pp. 25-35. Blackwell Scientific Publications, Oxford, UK.

Povolny, D. (1980) Die bisher bekannten Futterpflanzen der Tribus Gnorimoschemini (Lepidoptera, Gelechiidae) und deren Bedeutung für taxonomisch-ökologische Erwägungen. Acta Universitatis Agriculturae, Brno. Facultas Agronomica, 28, 189-210.

Proudfoot, A.M. (1993) Relationships between Coleophora atriplicis and its host plants on a salt marsh. PhD Thesis, University of East Anglia, Norwich, UK.

Rand, T.A. (1999) Effects of environmental context on the susceptibility of Atriplex patula to attack by herbivorous beetles. Oecologia, 121, 39-46.

Rand, T.A. (2000) Seed dispersal, habitat suitability and the distribution of halophytes across a salt marsh tidal gradient. Journal of Ecology, 88, 608-621.

Renard, C.M.G.C., Champenois, Y. \& Thibault, J.F. (1993) Characterizaton of the extractable pectins and hemicelluloses of the cell-wall of glasswort, Salicornia ramosissima. Carbohydrate Polymers, 22, 239-245.

Ribaut, H. (1952) Faune de France, Vol. 57: Homoptéres Auchenorhynques. II (Jassidae). Lechevalier, Paris, France.

Riehl, T.E. \& Ungar, I.A. (1982) Growth and ion accumulation in Salicornia europaea under saline field conditions. Oecologia, 54, 193-199.

Rivers, W.G. \& Weber, D.J. (1971) The influence of salinity and temperature on seed germination in Salicornia bigelovii. Physiologia Plantarum, 24, 73-75.

Rodwell, J.S., ed. (2000) British Plant Communities, Vol. 5. Maritime Communities and Vegetation of Open Habitats. Cambridge University Press, Cambridge, UK.

Rose, F. (1989) Key to annual Salicornia species of south England and north France. Botanical Society of the British Isles News, 53, 12-16.

Rowcliffe, J.M., Watkinson, A.R. \& Sutherland, W.J. (1998) Aggregative responses of brent geese on salt marsh and their impact on community dynamics. Oecologia, 114, 417-426.

Rozema, J. (1991) Growth, water and ion relationships of halophytic Monocotyledonae and Dicotyledonae: a unified concept. Aquatic Botany, 39, 17-33.

Rozema, J., Arp, W., van Diggelen, J., Kok, E. \& Letschert, J. (1987) An ecophysiological comparison of measurements of the diurnal rhythm of the leaf elongation and changes of the leaf thickness of salt-resistant Dicotyledonae and Monocotyledonae. Journal of Experimental Botany, 38, 442-453.

(C) 2001 British Ecological Society, Journal of Ecology, 89, 681-707
Rozema, J., Luppes, E. \& Broekman, R. (1985) Differential response of salt-marsh species to variation of iron and manganese. Vegetatio, 62, 293-301.

Rozema, J., van der List, J.C., Schat, H., van Diggelen, J. \& Broekman, R.A. (1987) Ecophysiological response of Salicornia dolichostachya and Salicornia brachystachya to seawater inundation. Vegetation Between Land and Sea (eds A.H.L. Huiskes, C.W.P.M. Blom \& J. Rozema), pp. 180186. Dr W. Junk, Dordrecht, The Netherlands.

Salt, T.A. \& Adler, J.H. (1985) Diversity of sterol composition in the family Chenopodiaceae. Lipids, 9, 594-601.

Sánchez, J.M., Izco, J. \& Medrano, M. (1996) Relationships between vegetation zonation and altitude in a salt-marsh system in norhwest Spain. Journal of Vegetation Science, 7, 695-702.

Schat, H., van der List, J.C. \& Rozema, J. (1987) Ecological differentiation of the microspecies Salicornia dolichostachya Moss and Salicornia ramosissima J. Woods: growth, mineral nutrition, carbon assimilation and development of the root system in anoxic and hypoxic culture solution. Vegetation Between Land and Sea (eds A.H.L. Huiskes, C.W.P.M. Blom \& J. Rozema), pp. 164-178. Dr W. Junk, Dordrecht, The Netherlands.

Scott, A.J. (1977) Reinstatement and revision of Salicorniaceae J. Agardh (Caryophyllales). Botanical Journal of the Linnean Society, 75, 357-374.

Singer, C.E. \& Havill, D.C. (1985) Manganese as an ecological factor in salt marshes. Vegetatio, 62, 287-292.

Smith, M.H. (1985) Life-histories of annual plants in a heterogeneous salt marsh environment. $\mathrm{PhD}$ Thesis, University of East Anglia, Norwich, UK.

Soó, R. (1960) Über südosteuropäische Salicornien. Acta Botanica Academiae Scientiarum Hungaricae, 6, 397403.

Stace, C.A. (1997) New Flora of the British Isles, 2nd edn. Cambridge University Press, Cambridge, UK.

Stanghellini, M.E., Mihail, J.D., Rasmussen, S.L. \& Turner, B.C. (1992) Macrophomina phaseolina - a soilborne pathogen of Salicornia bigelovii in a marine habitat. Plant Disease, 76, 751-752.

Stanghellini, M.E., Werner, F.G., Turner, B.C. \& Watson, M.C. (1988) Seedling death of Salicornia attributed to Metachroma (Coleoptera. Chrysomelidae, Eumolpinae) larvae. Southwestern Entomologist, 13, 305.

Stewart, G.R., Larher, F., Ahmad, I. \& Lee, J.A. (1979) Nitrogen metabolism and salt-tolerance in higher plants. Ecological Processes in Coastal Environments (eds R.L. Jefferies \& A.J. Davy), pp. 211-227. Blackwell Scientific Publications, Oxford, UK.

Stienstra, A.W. (1987) Salicornia europaea agg., colonizing bare sand flats in the south-west of the Netherlands. Vegetation Between Land and Sea (eds A.H.L. Huiskes, C.W.P.M. Blom \& J. Rozema), pp. 188-199. Dr W. Junk, Dordrecht, The Netherlands.

Stumpf, D.K., Prisco, J.T., Weeks, J.R., Lindley, V.A. \& O’Leary, J.W. (1986) Salinity and Salicornia bigelovii Torr. seedling establishment. Water relations. Journal of Experimental Botany, 37, 160-169.

Summers, R.W., Stansfield, J., Perry, S., Atkins, C. \& Bishop, J. (1993) Utilization, diet and diet selection by Brent geese, Branta bernicla bernicla, on salt marshes in Norfolk. Journal of Zoology, 231, 249-273.

Tolkën, H.R. (1967) The species of Arthrocnemum and Salicornia (Chenopodiaceae) in southern Africa. Bothalia, 9, 255-307.

Truscott, A.J. (1978) Growth of Enteromorpha and salt marsh development in the Stour estuary, Essex. $\mathrm{PhD}$ Thesis, University of East Anglia, Norwich, UK.

Tsuda, M. (1961) Studies on the halophilic characters of the strand dune plants and of the halophytes in Japan. Japanese Journal of Botany, 17, 332-370. 
Salicornia L.
Uffen, R. \& Chandler, P. (1978) A Dipterist's Handbook (eds Stubbs, A. \& Chandler, P.), Vol. 15, pp. 213-236. Amateur Entomologist's Society, London, UK.

Ungar, I.A. (1977) Salinity, temperature and growth regulator effects on seed germination in Salicornia europaea L. Aquatic Botany, 3, 329-335.

Ungar, I.A. (1978) Halophyte seed germination. Botanical Review, 44, 233-264.

Ungar, I.A. (1979) Seed dimorphism in Salicornia europaea L. Botanical Gazette, 140, 102-108.

Ungar, I.A. (1987a) Population characteristics, growth, and survival of the halophyte Salicornia europaea. Ecology, $\mathbf{6 8}$, $569-575$.

Ungar, I.A. (1987b) Population ecology of halophyte seeds. Botanical Review, 53, 301-334.

Ungar, I.A., Benner, D.K. \& McGraw, D.C. (1979) The distribution and growth of Salicornia europaea on an inland salt pan. Ecology, 60, 329-336.

Ungar, I.A. \& Riehl, T.E. (1980) The effect of seed reserves on species composition in zonal halophyte communities. Botanical Gazette, 141, 447-452.

Ungar, I.A. \& Woodell, S.R.J. (1996) Similarity of seed banks to above ground vegetation in grazed and ungrazed salt marsh communities on the Gower Peninsula, South Wales. International Journal of Plant Sciences, 157, 746-749.

Walsh, G.B. \& Dibb, J.R. (1954) Plants and the beetles associated with them. Amateur Entomologist, 11, 83-98.

Watkinson, A.R. \& Davy, A.J. (1985) Population biology of salt marsh and sand dune annuals. Vegetatio, 72, 487-497.

Weete, J.D., Rivers, W.G. \& Weber, D.J. (1970) Hydrocarbon and fatty acid distribution in the halophyte, Salicornia bigelovii. Phytochemistry, 9, 2041-2045.
Westhoff, V. \& Schouten, M.G.C. (1979) The diversity of European coastal ecosystems. Ecological Processes in Coastal Environments (eds R.L. Jefferies \& A.J. Davy), pp. 3-21. Blackwell Scientific Publications, Oxford, UK.

Wiehe, P.O. (1935) A quantitative study of the influence of the tide upon populations of Salicornia europaea. Journal of Ecology, 23, 323-333.

Wilkon-Michalska, J. (1985) Structure and dynamics of the inland populations of Salicornia patula Duval-Jouve. Vegetatio, 61, 145-154.

Willis, A.J. (2000) The changing structure and vegetational history of the 85-year-old saltmarsh at Berrow, North Somerset. British Saltmarshes (eds B.R. Sherwood, B.G. Gardiner \& T. Harris), pp. 65-80. Linnean Society/Forrest Text, Ceredigion, UK.

Wilson, P.G. (1980) A revision of the Australian species of Salicornieae (Chenopodiaceae). Nuytsia, 3, 3-154.

Wolff, S.L. \& Jefferies, R.L. (1987a) Morphological and isozyme variation in Salicornia europaea (s.1.) (Chenopodiaceae) in northeastern North America. Canadian Journal of Botany, 65, 1410-1419.

Wolff, S.L. \& Jefferies, R.L. (1987b) Taxonomic status of diploid Salicornia europaea (s.1.) (Chenopodiaceae) in northeastern North America. Canadian Journal of Botany, 65, 1420-1426.

Woods, J. (1851) On the various forms of Salicornia. Botanical Gazette, 3, 29-33.

Wulff, H.D. (1936) Die Polysomatie der Chenopodiaceen. Planta, 26, 275.

Wulff, H.D. (1937) Karyologische Untersuchungen an der Halophytenflora Schleswig-Holsteins. Jahrbuch für Wissenschaftlich der Botanik, 84, 812-840. 